Winter 2010

\title{
Pursuing Health as Foreign Policy: The Case of China
}

Yanzhong Huang

Seton Hall University

Follow this and additional works at: https://www.repository.law.indiana.edu/ijgls

Part of the Health Law and Policy Commons, International Law Commons, and the Law and Politics Commons

\section{Recommended Citation}

Huang, Yanzhong (2010) "Pursuing Health as Foreign Policy: The Case of China," Indiana Journal of Global Legal Studies: Vol. 17 : Iss. 1 , Article 6.

Available at: https://www.repository.law.indiana.edu/ijgls/vol17/iss1/6

This Symposium is brought to you for free and open access by the Law School Journals at Digital Repository @ Maurer Law. It has been accepted for inclusion in Indiana Journal of Global Legal Studies by an authorized editor of Digital Repository @ Maurer Law. For more information, please contact rvaughan@indiana.edu.

\section{$\Psi$}

JEROME HALL LAW LIBRARY

$$
\begin{aligned}
& \text { INDIANA UNIVERSITY } \\
& \text { Maurer School of Law }
\end{aligned}
$$




\title{
Pursuing Health as Foreign Policy: The Case of China
}

\author{
YANZHONG HUANG*
}

\section{Introduction: Health, Foreign Policy, AND China}

"Health is today a growing concern in foreign policy," the DirectorGeneral of the World Health Organization (WHO) announced with the foreign ministers of Norway and France in an editorial last year. ${ }^{1}$ Although health has long been a foreign policy issue, ${ }^{2}$ health was historically separate from foreign policy: the study and practice of foreign policy neglected public health, and public health was predominantly a domestic policy concern. ${ }^{3}$ It was not until the 1980 s that an unprecedented collision of the worlds of health and foreign policy began to occur. Events and developments in the political and epidemiological world-globalization, the rise of infectious disease, and the end of the Cold War-highlighted the importance of health as a key element of development and security policy. This, in turn, led to an epistemological change in both policy and academic circles. In September 2006, the foreign affairs ministers of seven countries

* Associate Professor and Director of the Center for Global Health Studies, John C. Whitehead School of Diplomacy and International Relations, Seton Hall University; Editor, Global Health Governance: The Scholarly Journal for the New Health Security Paradigm. This paper was completed while the author was a Visiting Senior Research Fellow at the East Asian Institute of the National University of Singapore.

1. Margret Chan et al., Foreign Policy and Global Public Health: Working Together Towards Common Goals, 86 BULL. OF THE WORLD HEALTH ORG. 498, 498 (2008).

2. See Vincanne Adams et al., Global Health Diplomacy, 27 MED. ANTHROPoLOGY 315, 316, 322 n.1 (2009). See generally Alexandra Minna Stern \& Howard Markel, International Efforts to Control Infectious Diseases, 1851 to the Present, 292 JAMA 1474 (2004) (reviewing 3 historical eras of international approaches to controlling infectious diseases). In 1851, the first International Sanitary Conference was held in Paris and was attended by diplomats and physicians from 11 European countries, which set the stage for future international health diplomacy efforts. Id. at 1475 .

3. See Randy Cheek, Public Health as a Global Security Issue, Foreign SERVICE J., Dec. 2004, at 22, 23; Ilona Kickbusch, Global Health Governance: Some Theoretical Considerations on the New Political Space, in Health IMPACTS OF Globalization: TOWARDS Global GoverNANCE 192, 200 (Kelley Lee ed., 2003).

Indiana Journal of Global Legal Studies Vol. 17 \#1 (Winter 2010) (C) Indiana University Maurer School of Law 
launched the Global Health and Foreign Policy Initiative. Bemoaning that "health is one of the most important, yet still broadly neglected, long-term foreign policy issues of our time," the ministers agreed to make impact on health "a point of departure and a defining lens" that each country would use to examine key elements of foreign policy and development strategies. ${ }^{4}$ In academia, growing awareness of a transformation in the health-foreign policy relationship produced a proliferation of global health programs as well as an emerging literature centered on health and foreign policy.

Despite the growing political and academic interest in health as a foreign policy issue, much of the emerging scholarship has focused on the conceptual overview of the field or particular aspects of the healthforeign policy linkage (e.g., humanitarian action). ${ }^{5}$ Little in-depth analysis has been conducted on how major powers engage health as a foreign policy issue. As a result, there is limited knowledge of their views on the relationship between health and foreign policy, the dynamics of power and interests in this relationship, and the implications of such dynamics for global health governance. The lack of scholarship in this area is no surprise, as the structure of global health governance began to take shape in an age of "nonpolarity" featuring multiple actors and political levels, each possessing and exercising various kinds of power. ${ }^{6}$ Yet, despite the rise of this "market multilateralism," nation states remain at the core of health governance. ${ }^{7}$ Not only do governments increasingly address health as a key function of foreign policy, but international health activities continue to reflect the desires and interests of the great powers. ${ }^{8}$

Among the major powers, China plays a critical role in the complex dynamics among health, prosperity, and security. It has one-fifth of the world's population and one-seventh of the world's disease burden,

4. Celso Amorim et al., Oslo Ministerial Declaration - Global Health: A Pressing Foreign Policy Issue of Our Time, 369 THE LANCET 1373, 1373 (2007).

5. For an example of current scholarship on health and foreign policy that does not examine how major powers use health to further their foreign policy objectives, see WHO, Special Theme Issue: Health and Foreign Policy, 86 BULL. OF THE WORLD HEALth ORg. 161 (2007).

6. See Richard N. Haas, The Age of Nonpolarity: What Will Follow U.S. Dominance, Foreign AFF., May-June 2008, at 44, 44-45. See generally Ilona Kickbusch, Moving Global Health Governance Forward, in MAKING SENSE OF GLOBAL HEALTH GovERnANCE: A Policy Perspective 320 (Kent Buse et al. eds., 2009) (discussing the international dynamics of a nonpolar world and the need for a new discourse on global health).

7. See Kickbusch, supra note 6, at 325.

8. David P. Fidler, Health as Foreign Policy: Between Principle and Power, WHITEHEAD J. DIPL. \& INT'L AFF., Summer-Fall 2005, at 179, 189. 
measured in years of healthy life lost. ${ }^{9}$ Historically, some major disease outbreaks in China, including the 1957 Asian flu, the 1968 Hong Kong flu, and the 2003 SARS epidemic, have triggered epidemics elsewhere in the world. As demonstrated in the SARS epidemic, the resulting spillover of disease outbreaks in China can have serious implications for stability, prosperity, and security at the regional and global levels.

This article examines the dynamics of the health-foreign policy nexus in China. After an overview of the Maoist health diplomacy, it discusses the elevation of health issues in the hierarchy of foreign policy objectives in China's reform era. Next, the article analyzes China's SARS diplomacy, which further demonstrates the changing landscape of health and foreign policy in China. Then I analyze the defining features and dilemmas of China's health-foreign policy interaction. While the emergence of health as an important foreign policy issue in China facilitates the fulfillment of its foreign policy goals and makes important contributions to international health cooperation, I conclude that the tensions and dilemmas inherent in the health-foreign policy mix in China pose risks and challenges to global health governance.

\section{The MaOIST HeaLTH DiPlomacy}

China has long been an important contributor to global health simply because of the sheer size of its population. By the 1970s, the Maoist health model, with its emphasis on equality, primary health care, community participation, and devolved decision making, not only improved the health status of 22.5 percent of the world's population, but it also significantly influenced the agenda of WHO. Encouraged by China's success, WHO declared in 1978 that "health for all" by the year 2000 was achievable through primary health care. ${ }^{10}$

However, this Chinese contribution was driven by neither concern about the possible spread of infectious diseases nor the potential benefits improved world health might bring to the international system. Against the backdrop of the Cold War, China's participation in international cooperation on health was very limited. In the face of the U.S.-led blockade, it chose to "lean toward one side" by prioritizing health-related international cooperation with socialist countries. Not surprisingly, almost all of China's health-related cooperation agreements were with nations in the Soviet bloc.

9. WHO, China to Study Links Between Sustainable Development and Investment in Health, Dec. 18, 2002, available at http://www.who.int/mediacentre/news/releases/pr96/ en/.

10. See Paul Johnstone \& Isobel McConnan, Primary Health Care Led NHS: Learning from Developing Countries, 311 BRIT. MED. J 891, 891 (1995). 
In the early 1960 s, with the deterioration of Sino-Soviet relations and the continuation of Sino-American confrontation, China needed to break its diplomatic isolation. As a result, China attached great importance to the "intermediate zones" (zhongjian didai) separating the two superpowers: the developing world, comprised of Asia, Africa, and Latin America; and the rest of the industrialized world, including Western Europe, Canada, Australia, and Japan. ${ }^{11}$ This foreign policy reorientation led to the establishment of official and nonofficial healthrelated exchange programs with developing countries as well as with some Western countries, such as Canada.

The launch of the Cultural Revolution in the mid-1960s saw the radicalization of China's foreign policy and efforts to "export revolution." China's role as a revisionist country in the international system became obvious when Mao's revolutionary strategy of "encirclement of the cities by the countryside" was transposed to an international strategy of surrounding "the cities of the world" (i.e., the industrial continents) from "the countryside of the world" (i.e., underdeveloped continents), a strategy which is fundamentally contrary to a system of nation-states. ${ }^{12}$ This foreign policy shift coincided with national liberation movements worldwide. Consequently, China ceased its exchange programs with Western countries and utilized foreign aid to expand its political influence in a large number of newly independent states.

Similar to Cuba, China made medical assistance part of exporting revolution. In April 1963, the first Chinese foreign aid medical team arrived in newly independent Algeria, where the war of national liberation against France had resulted in a mass exodus of the physicians, teachers, civil servants, and skilled workers. From that point on, China sent a steady trickle of medical teams to the African continent. The administrative structure of the medical teams demonstrated that China was using them as an instrument of health diplomacy. Although health bureaus in twenty-six provincial units assembled the medical teams, the management of the teams was not the responsibility of the Ministry of Health, but instead the Ministry of Foreign Affairs and the Ministry of Economics and Trade. Operated like the U.S. Peace Corps, but with an exclusive focus on medical care, each Chinese medical team was typically composed of ten to fifteen physicians, laboratory technicians, and assistants. Between 1963 and

11. Mao Zedong, Zhongjian didai you liangge [There are Two Intermediate Zones], in MAO ZEDONG WAIJIAO WENXUAN [SELECTED DIPLOMATIC WORKS OF MAO ZEDONG] 506-09 (1994).

12. Lin Piao, Long Live the Victory of the People's War - Commemorating the 20TH ANNIVERSARY OF THE VICTORY OF THE ANTI-JAPANESE WAR OF THE CHINESE PEOPLE 49 (Foreign Languages Press 1966) (1965). 
1982, 6,500 Chinese health workers joined the medical teams and served a total of seventy million people in forty-two countries. Three quarters of the recipient countries (thirty-two) are in Africa, a regional priority of China's foreign policy (see Table 1).

Table 1. Recipient Countries for China's Medical Teams (19631982), by Region

\begin{tabular}{ll}
\hline Region & Country \\
\hline Africa & $\begin{array}{l}\text { Algeria, Zanzibar (Tanzania), Somalia, Congo, Mali, } \\
\text { Tanganyika (Tanzania), Mauritania, Guinea, Sudan, } \\
\text { Equatorial Guinea, Sierra Leone, Tunisia, Zaire, } \\
\text { Togo, Senegal, Madagascar, Morocco, Niger, } \\
\text { Mozambique, São Tomé and Príncipe, Upper Volta } \\
\text { (Burkina Faso), Guinea-Bissau, Gabon, Gambia, } \\
\text { Benin, Zambia, Central African Republic, Botswana, } \\
\text { Djibouti, Rwanda, Ethiopia, Cameroon, }{ }^{*} \text { Chad* }\end{array}$ \\
\hline Middle East & $\begin{array}{l}\text { North Yemen, South Yemen, Kuwait, United Arab } \\
\text { Emirates, Syria, }{ }^{*} \text { Iran* }\end{array}$ \\
\hline Southeast Asia & Laos, ${ }^{*}$ Vietnam, ${ }^{*}$ Cambodia* \\
\hline * Dispatch discontinued due to expiration of the agreement or \\
deterioration of diplomatic relations.
\end{tabular}

Source: China Health Y.B. 1983, 378, 386.

The dispatch of the medical teams bore the firm imprint of the Maoist policy structure. Chinese medical teams usually brought their own equipment and medicines. Until 1978, they provided services, in addition to some material supplies, completely free of charge, despite requests of some recipient countries to chip in. ${ }^{13}$ Most of the medical teams operated in outlying areas where access to health care was difficult or impossible for local people to obtain. In doing so, they focused more on preventive care than on emergency medical care. ${ }^{14}$ Their services reportedly helped win China friendship in the third world,

13. Zhou Jianping, Dui woguo yuanwai yiliaodui youguan wenti tantao [Investigating Problems Related to Our Country's Foreign-aid Medical Teams], ZHONGGUO WEISHENG JINGJ [CHINESE HEALTH ECON.], issue no. 3, 1984, at 39, 39 (P.R.C.).

14. ALAN HutCHISON, CHINA'S AFRICAN REVOLUTION 220-21 (1975). 
especially in Africa. A spokesman for China's Ministry of Foreign Affairs has expressed the belief that the work of the medical teams played a positive role in China's 1971 admission to the U.N. ${ }^{15}$ A report of the Joint Economic Committee of the U.S. Congress concurred by concluding that " $[\mathrm{m}]$ edical services have proven one of China's most effective economic aid programs in the Third World." 16 By the end of 1982, Chinese medical teams were still active in twenty-nine African countries. ${ }^{17}$

The frequency of health intersecting with Chinese foreign policy increased in the 1970s, when China resumed its membership at the U.N. and WHO. In September 1972, China signed the Basic Agreement with the U.N. Development Programme (UNDP), which allowed UNDP to fund projects covering areas of health-manpower development, medical information, traditional medicine, pharmaceutical standards, and primary health care. In December 1978, the Ministry of Health signed a historic Memorandum of Understanding with WHO, which designated forty-one research institutes in China as WHO Cooperation Centers. As part of this deal, China paid membership dues of U.S.\$15.1 million for the years 1980-1981 and U.S.\$7.6 million for 1982-1983. In addition to its participation in WHO, China also began to contribute to the United Nations Children's Fund (UNICEF). Soon, it used loans from the World Bank to improve medical education and rural health care. At almost the same time, China and the United States began to cooperate under the auspices of a Health Protocol signed in 1979.

Despite its expanding interest in health diplomacy, China's engagement in international health remained limited in scope and symbolic in nature. Until the early 1980s, foreign policy shaped the Chinese government's health agenda in the developing world, not vice versa. In the words of Fidler, health for China in this time period was "merely another issue with which traditional approaches to foreign policy grapple."18 Because of China's hostility toward multilateralism, much of its health diplomacy was conducted bilaterally. Since it regarded the international system as alien and illegitimate, the issue of China being a responsible power in the system was not part of the foreign policy agenda. China's lack of significant interaction with the

15. Lu Haiwen, Zhongguo yuanwai yiliaodui: 40 nian qingqing zhenzhi 2.4 yi renci [Chinese Foreign-aid Medical Teams: Heartily Treating 240 Million Patients Over Forty Years], Huaxia Shibao [Huaxia Tmes] (P.R.C.), Dec. 3, 2003, at 7.

16. Carol Fogarty, Chinese Relations with the Third World, in 1 CHINESE ECONOMY Post-MaO: A COMPENDIUM OF PAPERS SUBMITTED TO THE JOINT ECONOMIC COMMITTEE CONGRESS OF THE UNITED STATES 856 (1978).

17. China HealTh Y.B. 1983386.

18. Fidler, supra note 8 , at 184. 
outside world not only allowed a clear demarcation between domestic and international health, but it also reduced the need to respond to international demands and pressures over health issues.

\section{The Changing Chinese Landscape of Health AND FOREIGN POLICY}

In 1982, as "politics in command" gave way to a developmentcentered agenda, China restructured its foreign aid policy to focus on economic interests, reciprocity, and diversity in cooperation. ${ }^{19}$ The changing aid policy priorities, coupled with the growing call for "acting in accordance with market laws" (an shichang guilu banshi), led to significant changes in the funding of foreign aid medical teams. By the early 1980 s, sixty percent of the recipient countries were contributing to the financing of the Chinese medical teams, and only eleven percent still received medical aid for free. ${ }^{20}$ For those countries that shouldered the full cost, the medical teams were no longer part of China's "foreign aid" package. ${ }^{21}$ When the medical teams started charging patients fees, it further undermined China's ability to leverage medical teams as a foreign policy instrument. ${ }^{22}$

In China, the market-oriented economic reforms reinforced the idea of pursuing economic solutions to social policy problems and transformed hospitals into profit-making machines. ${ }^{23}$ In this context, the growing opportunity cost meant health workers became reluctant to join the foreign aid medical teams, while hospitals had few incentives to send out experienced physicians. Stagnating government funding and growing demands from recipient countries for more high-end care exacerbated the difficulty in dispatching medical teams. ${ }^{24}$ As economic

19. See Zhang Yuhui, Zhongguo duiwai yuanzhu yanjiu [A Study of China's Foreign Aid] 117-18 (Mar. 2006) (Ph.D. dissertation, Central Party School) (P.R.C.).

20. The remaining 29 percent paid for the services with loans provided by the Chinese government. See Zhou Jianping, supra note 13.

21. See Liu Zhenguo \& Zheng Yurong, Dui yuanwai yiliaodui gaige de ji dian sikao [Several Reflections on the Reform of Foreign-Aid Medical Teams], YIXUE YANJIU TONGXUN [MED. RES. CORRESPONDENCE], issue no. 10, 1997, at 49 (P.R.C.).

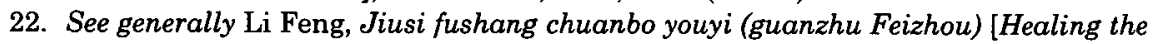
Wounded and Rescuing the Dying, Spreading Friendship (Focus on Africa)], RENMN RIBAO [PEOPLE'S DAILY] (P.R.C.), Dec. 16, 2006, at 3, available at http://paper.people.com.cn/rmrb/html/2006-12/16/content_12109978.htm (describing certain hospital fees charged by a Chinese medical team at a hospital in Madagascar).

23. Yanzhong Huang, The Paradoxical Transition in China's Health System, HARv. HEALTH POL'Y REV., Spring 2002, at 78, available at http://www.hcs.harvard.edu/ epihc/ currentissue/spring2002/huang.php.

24. China annually budgeted RMB100-200 million for foreign aid medical teams. See Huang Xuan, Yuanwai yiliao gongzuo yunniang shang xin taijie [Medical Foreign-Aid 
efficiency considerations lessened the political nature of sending out medical teams, the quality and discipline of the medical teams slipped. In August 2001, Belgian police arrested fifteen Chinese medical staff on their way home from Mali in the Brussels International Airport on suspicion that they were smuggling ivory and ivory products. They were released, but the international image of Chinese medical teams was tarnished. ${ }^{25}$

In view of China's limited engagement in international health, adopting a foreign policy stance that gave greater priority to health issues would require reassessing the way China related to the rest of the world. In the 1950s and 1960s, Chinese foreign policy rejected the dominant norms of the international society and sought to articulate new conceptions based on its own revolutionary vision. ${ }^{26}$ The end of the Cold War and China's integration into the world economy led to soulsearching for China's "identity" in the international system. During the 1990 s, China developed a new sense of accountability and commitment in its interactions with the outside world. As Johnston observed, on major global issues, such as international trade and arms control, China has become "more integrated into and more cooperative within international institutions than ever before." 27 Much of this more positive foreign policy behavior reflects China's wish to be viewed not as a rule breaker or a challenger, but as an internationally responsible state that actively engages in international affairs, even though moving in this direction entails acceptance of more restraints on its sovereignty. ${ }^{28}$

China's new identity also prompted new thinking about the meaning of security and international cooperation. Although the Chinese government did not officially adopt the term "non-traditional security" (NTS) until 2001, it unveiled its "new security concept" as early as 1996 at the Regional Forum of the Association of Southeast Asian Nations (ASEAN). The new security concept, constituting the core of China's foreign policy strategy, was elaborated in a position paper submitted to the Forum in July 2002. According to the paper, the essence of the new security concept is to "rise above one-sided security

Work Considers Entering a New Stage], RENMIN ZHENGXIE BAO [PEOPLE'S POL. Consultative Daily] (P.R.C.), Dec. 10, 2003.

25. See Wu Ang, Zhongguo yisheng he Feizhou daxiang [Chinese Doctors and African Elephants], SANLIAN SHENGHUo ZhouKan [LIFE WEEK], issue no. 33, 2001 (P.R.C.), available at http://www.chinanews.com.cn/zhonghuawenzhai/2001-11-01/txt/22.htm.

26. See Rosemary Foot, Chinese Power and the Idea of a Responsible State, 45 CHINA J. 1, 4-6 (2001).

27. Alastair Iain Johnston, Is China a Status Quo Power?, INT'L SECURITY, Spring 2003 , at 5,49 .

28. See Foot, supra note 26, at 15; see also WANG YIZHOU, QUANQIU ZHENGZH HE ZHONGGUO WAIJIAO [GLOBAL POLITICS AND CHINA'S FOREIGN POLICY] 184-85 (2003). 
and seek common security through mutually beneficial cooperation."29 In December 2002, an official document formally included tackling NTS threats as part of China's national defense. ${ }^{30}$

The development of the new security concept changed the discourse of Chinese foreign policy, allowing into the policy process a wide range of nontraditional and nonmilitary issues. It also connected national security to international security. A joint declaration signed between China and ASEAN in November 2002, for example, recognized that China and ASEAN shared "extensive common interests" in coping with NTS threats and emphasized the need to strengthen regional and international cooperation. ${ }^{31}$ Chinese leaders apparently fell under the sway of this paradigmatic shift. Then-President Jiang Zemin said that as "countries increase their interdependency and common ground on security, it has become difficult for any single country to realize its security objective by itself alone. Only by strengthening international cooperation can we effectively deal with the security challenge worldwide and realize universal and sustained security." 32

Neither the July 2002 position paper nor the November 2002 joint declaration specified health problems as a NTS threat, but Chinese government leaders soon felt the international pressure to do so. In June 2002, a U.N. report entitled "HIV/AIDS: China's Titanic Peril" was released, raising the specter that the disease could rapidly spread among the general population in China. ${ }^{33}$ Chinese officials rejected the report, but it became increasingly clear that HIV/AIDS is not just a public health problem, but also one that has significant social, economic, political, and security implications, and therefore demands the highest level of political attention. ${ }^{34}$

29. Ministry of Foreign Affairs, China's Position Paper on the New Security Concept (July 31, 2002).

30. See Information Office of the State Council, China's National Defense in 2002 (Dec. 9, 2002), available at http://www.china.org.cn/e-white/20021209/index.htm.

31. See Joint Declaration of ASEAN and China on Cooperation in the Field of NonTraditional Security Issues, Nov. 4, 2002, available at http://www.aseansec.org/13186.htm.

32. Jiang Zemin, President, P.R.C., Address at German Foreign Policy Association: Together Create a New Century of Peace and Prosperity (Apr. 10, 2002).

33. See U.N. Theme Group on HIV/AIDS in China, HIV/AIDS: China's Titanic Peril 2001 Update of the AIDS Situation and Needs Assessment Report, at 7 (June 2002), available at http://www.hivpolicy.org/Library/HPP000056.pdf.

34. An editorial in the People's Daily warned that if measures were not taken by all levels of the Chinese government and the Chinese people in general, the number of HIV cases could reach 10 million by 2010, causing RMB7.7 trillion in economic losses. Yang Ruoqian, Editorial, Curbing AIDS Proliferation, No Time for China to Delay Any Longer, PEOPLE'S DAILY, July 24, 2002, available at http://english.peopledaily.com.cn/ 200207/24/eng20020724_100289.shtml. 
The shift to a new security agenda is not simply a technical issue; it also leads to the reorientation of the national development agenda. Many nontraditional security challenges, such as the spread of infectious disease, are nonmilitary in nature but pose direct threats to the safety of societies and individuals, and thus fall under the category of "human security." 35 The focus on the welfare and quality of peoples' lives as the primary object of security was emphasized by former Canadian Foreign Minister Lloyd Axworthy, who made it clear that "[f]rom a foreign policy perspective, human security is best understood as a shift in perspective or orientation. It is an alternative way of seeing the world, taking people as its point of reference rather than focusing exclusively on the security of territory or governments." 36

According to a Chinese scholar, the rise of "human security" and the people-centered approach it entails also called for a broad restructuring of state-society relations. He used the cases of Iraq under Saddam Hussein and Indonesia under Suharto to argue that "national security" was the least secure if pursued at the expense of human security and social stability. ${ }^{37} \mathrm{He}$ further argued that NTS problems are often associated with the legitimacy and effectiveness of a country's sociopolitical system. Most of China's NTS problems "are rooted in the inadequacy of the economic structure and political system, and often spread and deteriorate because of power holders' bureaucratic selfassertiveness and indifference." 38 Indeed, prior to the SARS outbreak, public health had become the least of Chinese leaders' concerns. ${ }^{39}$

The leadership transition from November 2002 increased the incentives of a new generation of leaders to strike a theme different from their predecessors. In March 2003, the Party General Secretary $\mathrm{Hu}$ Jintao indicated his emphasis on human security by promising to "exercise power for the people, feel as the people feel and work for their happiness." 40 This people-centered approach gained more currency after

35. See Roland Paris, Human Security: Paradigm Shift or Hot Air?, 26 INT'L SECURITY 87, 96-97 (2001) (explaining that "human security" can serve as a broad label for studies in the field of security issues that is primarily concerned with nonmilitary threats to the safety of individuals, groups, and societies).

36. Lloyd Axworthy, Minister of Foreign Affairs, Canadian Dep't of Foreign Aff. \& Int'l Trade, Concept Paper, Human Security: Safety for People in a Changing World (April 29, 1999), available at http://www.summit-americas.org/Canada/Humansecurity-english.htm.

37. Wang Yizhou, China and Non-Traditional Security, GUOJI JINGJI PINGLUN [REV. INT'L ECON.], Nov.-Dec. 2004, at 34.

38. Id. at 35 .

39. Ruan Ming, Deng XiaOPing: Chronicle of an Empire 189 (Nancy liu et al. trans., Westview Press 1994) (1992).

40. People's Daily Online, Hu Jintao Addresses NPC Session Closing Ceremony, http://english.peopledaily.com.cn/200303/18/eng20030318_113472.shtml (last visited Oct. $8,2009)$. 
China's initial response to the SARS outbreak turned out to be a fiasco, which prepared a favorable political environment for policy changes in addressing NTS threats in general, and public health challenges in particular.

In sum, market-oriented reforms and the end of the Cold War opened a window of opportunity for China to redefine its role in the international system. The constructivist attempts to become a responsible status quo power were accompanied by new thinking on the meaning and scope of security, which changed the discourse of foreign policy. The growing interest in NTS issues, coupled with the rhetoric of a people-centered approach to development, began to alter the landscape in which the health-foreign policy would operate in the new century.

\section{CHINA's SARS DIPLOMACY}

\section{A. SARS as a Foreign Policy Challenge}

The streams of problems, politics, and policy ideas alive in Chinese foreign policy at the turn of the century converged during the 2002-03 SARS outbreak. ${ }^{41}$ The crisis highlighted the potential devastating impact of health-related NTS threats. The SARS epidemic lasted less than eight months and killed no more than 700 people in China, but it shaved an estimated seven-tenths of a percentage point off China's gross domestic product for 2003, and probably caused the most serious social-political crisis since the 1989 Tiananmen crackdown.

In addition, SARS occurred when China had made great strides in improving its international image. The misgivings among the international community about China's initial handling of the crisis led to calls to "quarantine China" by suspending all travel links with the country until it implemented a transparent public health campaign. ${ }^{42}$ During the crisis, 110 out of the 164 countries with which China had diplomatic relations placed at least some restrictions on travel to China. ${ }^{43}$ As the official China Daily admitted, "The hard-won mutual trust between China and the international community was put to the test." 44 Moreover, the spread of SARS and furor over China's

41. Yanzhong Huang, The Politics of HIV/AIDS in China, 30 AsIAN PERSP. 95, 95-125 (2006).

42. Editorial, Quarantine China, WALL ST. J., Mar. 31, 2003, at A10.

43. Embassy of Switz., China Business Briefing No. 140 (May 12-18, 2003), available at http://www.sinoptic.ch/cbb/2003/cbb030512-030518.htm.

44. Pang Zhongying, Opinion, China Shows It Is Responsible, ChINA DaILY, June 30, 2003, at 4, available at http://www.chinadaily.com.cn/en/doc/2003-06/30/ 
mismanagement of the crisis expanded the rift between China and Taiwan. Taipei seized the opportunity to portray China as an irresponsible power that exports epidemics to Taiwan, yet refuses to allow Taiwan to seek direct help from WHO. The Health Minister of Taiwan even launched a notorious advertisement comparing the number of SARS cases to the number of communist spies hiding in Taiwan..$^{45}$

In recognition of both domestic and foreign policy challenges arising out of the SARS crisis, Premier Wen Jiabao said that "the health and security of the people, overall state of reform, development, and stability, and China's national interest and international image are at stake." ${ }^{46}$ Against this background, arguments about the negative downward spiral between infectious diseases, economic growth, socialpolitical stability, and national security gained more currency in Chinese academic and policy circles. As a Chinese scholar noted, more attention should now be paid to NTS threats, which cover not just terrorism, but also security in social fields such as communicable disease. ${ }^{47}$ The Ministry of Foreign Affairs (MOFA) echoed this opinion:

In the initial stages of SARS epidemic, we did not handle it as a non-traditional security factor in the context of globalization....The epidemic and related information had already spread before effective control methods were found. We did not turn around the passive situation in disease prevention and control as well as diplomacy work until the [Party] center adopted decisive measures. ${ }^{48}$

content_241840.htm.

45. SARS shi feidie? Weishu guanggao xiu guotou [Is SARS a Communist Spy? Ministry of Health Ad Overblown], LianHE Bao [UNITED DaILY News] (Taiwan), Apr. 1, 2003.

46. Tongyi sixiang, jiaqiang lingdao, luoshi zeren, qieshi zuohao feidianxing feiyan fangzhi gongzuo [Reaching a Common Understanding, Strengthening Leadership, Carrying Out Responsibilities, Feasibly Completing SARS Prevention and Treatment Work], PEOPLE'S DAILY, Apr. 14, 2003, at 1, available at http://www.people.com.cn/GB/ paper464/8941/834197.html.

47. Pang Zhongyin, Weinan zhong chongsu Zhongguo guoji xingxiang [Reshaping China's International Image Amidst Crisis], Wangluo Bao [NETWORK DaILY] (P.R.C), June 23, 2006, at 10 .

48. Waijiaobu zhengce yanjiushi [Ministry of Foreign Affairs Policy Lab.], Waijiao: zouxiang kaifang, touming yu hezuo [Diplomacy: Towards Openness, Transparency and Cooperation], SHIJIE ZHISHI [WORLD AFF.], issue no. 12, 2003, at 12 (P.R.C.) [hereinafter MOFA]. 
In November 2003, MOFA convened a special meeting to examine NTS threats, and, for the first time, HIV/AIDS was listed as one of the six NTS threats. ${ }^{49}$ In December 2003, the Chinese Academy of Social Sciences, a major government think tank, organized a national conference on NTS, the first of its kind in China. In view of the threat SARS posed to China, some participants went as far as to suggest that human security should be the foundation of Chinese national security. ${ }^{50}$

\section{B. Wrestling with WHO}

The SARS crisis not only led to the "securitization" of infectious disease in Chinese policy circles, but it also provided China with the opportunity to update its ideas about globalization and the role of international organizations. Fearing that the pro-independence authorities in Taiwan might exploit the epidemic to dissociate Taiwan from the mainland, China sought to control WHO's communication with and reporting on Taiwan. WHO initially did follow Beijing's demands. When the first cases appeared in Taiwan in March 2003, WHO asked the U.S. Centers for Disease Control and Prevention (CDC) to send experts rather than having WHO deal directly with Taiwan's problems. ${ }^{51}$ In early May, however, as Taiwan reported the rapid spread of SARS, WHO decided, for the first time, to send an advisory team of its own to Taiwan. Later, two additional WHO experts were dispatched. Before sending the advisory team, the health agency did seek approval from Beijing. ${ }^{52}$ Although Beijing reacted rapidly and positively to WHO's requests, it worried that doing so risked emboldening the island to seek more international political space. When meeting with WHO Director-General Dr. Gro Harlem Brundtland on May 18, Vice-Premier Wu Yi warned WHO against Taiwan's efforts to "politicize" the SARS crisis. ${ }^{53}$ In mid-June, however, WHO invited two speakers from Taiwan

49. Wang, supra note 37 , at 63 (listing the other 5 NTS threats aside from HIV/AIDS as money trafficking, piracy, excessive poverty, refugees and immigrants, and environmental security).

50. See He Zhongyi, "Feichuantong anquan yu Zhongguo": xueshu yantaohui zongshu ["Non-traditional Security and China": An Overview of the Academic Symposium], SHIJIE JINGJI YU ZHENGZHI [WORLD ECON. \& POL.], issue no. 3, 2004, at 48, 52 (P.R.C.).

51. David G. Brown, China-Taiwan Relations: The Shadow of SARS, COMP. ConNECTIONS, July 2003, I| 9, available at http://www.csis.org/files/media/csis/pubs/ 0302qchina_taiwan.pdf.

52. Interview with Dr. David Heymann, Assistant Director-General for Health Security and Environment, WHO, March 10, 2009.

53. See Chinese Vice Premier Wu Yi Meets WHO Chief, RENMIN RIBao (Beijing), May 19, 2003, available at $\mathrm{http}: / /$ english.peopledaily.com.cn/200305/19/ eng20030519_116894.shtml (English translation). 
to present at its global conference on SARS in Malaysia. Taiwan hailed the invitation as a "breakthrough" in its bid to join WHO. ${ }^{4}$ Beijing stated that it had shown flexibility by agreeing to Taiwan's participation, although the WHO spokesman said that the invitations had been extended without reference to Beijing. ${ }^{55}$ Much to Beijing's chagrin, the name badge of Taiwan's senior representative at the meeting identified him as "Director, CDC, Taiwan," without mention of China. ${ }^{56}$

Beijing initially also fought hard with WHO for its monopoly over disease control and response activities during the epidemic in mainland China. Until early April, the Chinese government was essentially in denial, sharing little information with WHO and even barring WHO experts from visiting Guangdong, the SARS epicenter. But each step taken by Beijing to reaffirm its sovereignty only generated more pressure for international scrutiny of its domestic health system, and justified more autonomous actions by WHO. On April 2, 2003, WHO issued the first travel advisory in its fifty-five-year history, advising people not to visit Hong Kong and Guangdong. Two weeks later, Beijing's spin control suffered another setback, when WHO took the unprecedented step of issuing a very public rebuke of China's actions, chastising Beijing for misleading the global community regarding the true extent of SARS infection throughout the country. ${ }^{57}$

When the Chinese leaders realized that their strategy of containing SARS only jeopardized its image as a responsible player in the international system, they tried to accommodate WHO demands in the anti-SARS campaign. Ironically, each concession from Beijing to satisfy WHO demands only strengthened WHO's authority and power to push for further concessions, so much so that WHO representatives were viewed as de facto supervisors of China's anti-SARS campaign. ${ }^{58}$ As observed by a Chinese scholar, during the SARS crisis WHO was as famous as the World Trade Organization in China because the Chinese people recognized the "indispensable authority" of WHO in global health affairs. ${ }^{59}$ By all accounts, WHO acted more like a referee rather than a junior partner in China's fight against SARS.

54. Melody Chen, SARS Team Ready for WHO Meet, TAIPEI TIMES, June 16, 2003, at 1 , available at http://www.taipeitimes.com/News/front/archives/2003/06/16/2003055430.

55. Brown, supra note 51, at I 11.

56. Id.

57. John Pomfret, Underreporting, Secrecy Fuel SARS in Beijing, WHO Says, WASH. POST, Apr. 17, 2003, at A16.

58. Simon Shen, The "SARS Diplomacy" of Beijing and Taipei: Competition Between the Chinese and Non-Chinese Orbits, 28 ASLAN PERSP. 45, 49 (2004).

59. Pang, supra note 47. 
On June 24, 2003, WHO lifted its travel warning for Beijing. The city's residents greeted the decision with enormous celebrations and relief. A statement from the official China National Tourism Association viewed the removal of WHO's warning as "a vote of confidence in our war on SARS and an important starting point for the recovery of China's tourism sector."60 During SARS, even one of the most ardent supporters of state sovereignty appeared to have acquiesced to WHO's leadership in international health governance. No wonder Fidler argued that the SARS outbreak put the final nail in the coffin of relying on traditional strategies for health governance. ${ }^{61}$

\section{Wen Jiabao's SARS Diplomacy}

The global spread of SARS and its foreign policy ramifications reinforced the perception of China as a stakeholder in the international system, generating strong incentives for China to deal with international cooperation in a more active and sincere manner. On April 26, 2003, Health Ministers of ASEAN+3 (ASEAN members plus China, Japan, and South Korea) met in Kuala Lumpur to voice their willingness to cooperate on health issues. Four days later, Premier Wen attended an emergency summit meeting with ASEAN leaders in Bangkok. According to the then Thai Premier Thaksin, it did not take long for Premier Wen to confirm his attendance.

Against the backdrop of the cross-boundary spread of SARS, Wen emphasized that the disease could "only be effectively countered by cooperative efforts at the regional and international levels." 62 Keenly aware that China's image and the reputation of the new leadership were at stake, Wen was very open, candid, and cooperative at the Bangkok meeting. He pleaded for understanding from other ASEAN leaders by stating: "[I]n the face of the outbreak of this sudden epidemic, we lack experience with its prevention and control. The crisis management mechanism and the work of certain localities and departments are not quite adequate."63 This statement constituted an astonishing admission of culpability from a regime that was loath to take responsibility for any

60. Paul Zach, SARS-Free Asia Goes All Out to Woo Tourists Back, THE STRAITS TimES (Singapore), June 26, 2003, available at http://yaleglobal.yale.edu/content/sars-free-asiagoes-all-out-woo-tourists-back.

61. David P. Fidler, Germs, Governance, and Global Public Health in the Wake of SARS, 113 J. CLINICAL INVESTIGATION 799, 801-02 (2004).

62. Wen Jiabao, Premier, P.R.C., Speech at the Special China-ASEAN Leaders' Meeting on SARS (Apr. 29, 2003), If 13, available at http://www.fmprc.gov.cn/eng/ topics/zgcydyhz/t26292.htm\#.

63. Id. at ๆ 3. 
mistake or wrongdoing. In the ASEAN-China joint statement, China agreed to "associate itself with the measures proposed by the ASEAN declaration." The seemingly half-hearted endorsement was indeed remarkable, given that a total acceptance of the measures decided by the ASEAN leaders would be perceived in China as an act of submission. ${ }^{64}$ To demonstrate its commitment to cooperation with ASEAN countries, China proposed the creation of a special fund against SARS. It pledged initial seed money of U.S.\$1.2 million, which was followed by donations from Thailand and Cambodia. ${ }^{65}$

Ultimately, the Bangkok Summit proved to be a win-win outcome for both China and Southeast Asia. For leaders in Southeast Asia, the health crisis reinvigorated ASEAN and served to equalize its relations with China. China, on the other hand, took advantage of the new dynamics created by the Summit to expand its influence in this region. In October 2003, China became the first ever "strategic partner" of ASEAN, which was seen as a victory over the suspicions that ASEAN members had long harbored toward China because of territorial disputes and ideological conflicts. ${ }^{66}$ In Singaporean Prime Minister Goh Chok Tong's words, the SARS crisis "may be the start of a new relationship between leaders in East Asia." 67

\section{The New Health-Foreign Policy Dynamics in China}

\section{A. A More Transparent and Cooperative China}

Under the punctuated equilibrium model, institutions are established in spurts: their structures, once established, tend to persist until the next crisis brings about a new spurt of institutional reconfiguration. ${ }^{68}$ Despite the tendency to get back to "business as usual," the SARS-induced policy and institutional innovations within China have largely been sustained. A joint declaration signed by ASEAN and China in Bali in October 2003, for instance, not only reiterated the determination of both sides to implement the consensus

64. Michael Vatikiotis, ASEAN and China - United in Adversity, FAR E. ECON. REv., May 8, 2003, at 14, 15.

65. Id. at 16 .

66. Susan Lawrence, Testing Wen's Mettle, FAR E. ECON. REV., Dec. 11, 2003, at 34, 37.

67. Vatikiotis, supra note 64, at 17.

68. Arthur L. Stinchcombe, Social Structure and Organizations, in HANDBOOK of ORGANIZATIONS 142, 154 (James G. March ed., 1965). On the episodic nature of institutional change, see G. John Ikenberry, Conclusion: An Institutional Approach to American Foreign Economic Policy, in The STATE and AmERICAN Foreign Economic PoulCY 219 (G. John Ikenberry et al. eds., 1988); Stephen Krasner, Sovereignty: An Institutional Perspective, 21 COMP. POL. STUD. 66 (1988). 
of the Special ASEAN-China Leaders' Meeting on SARS held in Bangkok the previous April, but it also promised to launch the "ten plus one" (ASEAN members plus China) health ministers meeting mechanism. The growing interest in international cooperation over health has been driven by an important lesson Beijing drew from SARS: in an age of globalization, it can no longer monopolize information or act alone in addressing NTS challenges. The Ministry of Foreign Affairs acknowledged this reality as follows:

Nontraditional security problems often go beyond the capability and jurisdiction of one single government. A government in the era of globalization is no longer an "omnipotent government," and its monopoly over information has been broken. Therefore, in dealing with a crisis, the government not only should first consider issuing warnings in a timely manner to its nationals, foreign residents as well as related countries that are likely harmed and affected, but should also actively seek international assistance and undertake international cooperation in order to strengthen its capability to address internal crises. Only by adopting such responsible and candid attitude can government's trustworthiness and cohesion be strengthened for the benefit of dealing with crises appropriately and reducing losses. ${ }^{69}$

Driven by this new thinking, China in the wake of SARS has been more willing to work with other countries on health issues. The 2003 Regulation on Public Health Emergencies (Article 7), the 2004 revised Law on Infectious Disease Prevention and Control (Article 8), and the 2007 Emergency Response Law (Article 17) all authorize government support of international cooperation on disease surveillance and response. China has also expanded its cooperation with other countries on a bilateral basis in disease prevention and control. Since 2002, it has established high-level health dialogue mechanisms with ASEAN, the United States, Russia, the United Kingdom, and Japan. In 2004, China organized the China-ASEAN special meeting on the control of avian influenza, which committed all parties to implement the meeting's recommendations. The same year, the annual U.S.-China Global Issues Forum began to provide a platform to discuss issues such as humanitarian assistance, public health, trafficking in persons,

69. MOFA, supra note 48 , at 13 . 
environmental conservation, and sustainable development. In 2006, the presidents of China and the United States agreed to create a Strategic Economic Dialogue (SED) to discuss long-term strategic challenges. Under the SED, dialogues over health and food and drug safety issues are handled by the (1) U.S.-China Health Care Forum involving the U.S. Department of Health and Human Services and the Chinese Ministry of Health, and (2) Joint Commission on Commerce and Trade involving the U.S. Department of Commerce, the U.S. Trade Representative, and the Chinese Vice Premier responsible for trade. ${ }^{70}$ In November 2008, amidst the growing concerns about the safety of its exports to the United States, China allowed the U.S. Food and Drug Administration to open in Beijing its first overseas office. ${ }^{71}$

The SARS crisis also forced the Chinese government to take steps to establish a more open and transparent government in dealing with public health issues. As part of the government transparency campaign, information on current veterinary epidemics, such as foot and mouth disease, swine vesicular disease, and avian influenza are no longer classified as state secrets. Mechanisms on communicating with the international society on public health emergencies have been established. Beginning in 2004, China has worked with UNAIDS to issue joint reports on China's AIDS spread and control. China's increasing candor and pragmatism in tackling AIDS compared more and more favorably to the approaches of India and Russia, which still seemed to be in denial. ${ }^{72}$ Following its acceptance of the International Health Regulations (2005), the Chinese government has also made important strides in cooperating with WHO and foreign scientists in sharing data and information about outbreaks. During the 2008 hand, foot, and mouth disease outbreak, the Ministry of Health disseminated six information newsletters to health departments in Hong Kong, Macau, and Taiwan while working closely with WHO on the prevention and control of the disease.

As China became more sensitive to its international image in addressing health challenges, it has been increasingly receptive to international influences and pressures. Following the delivery of only

70. See Joint Communique on the Second Meeting of the U.S.-China Health-Care Forum (May 22, 2007), available at http://www.export.gov/china/policyadd/

Joint_Communique_HC.pdf.

71. Calum MacLeod, FDA Opens Office in China, USA TODAY, Nov. 19, 2008, available at http://www.usatoday.com/news/washington/2008-11-19-chinafda_N.htm.

72. See Joseph Kahn, Business Urged to Help Fight Aids, N.Y. TIMES, March 19, 2005, available at http:/query.nytimes.com/gst/fullpage.html?res=9E02EED9113CF93AA 25750 C0A9639CB63 (reporting on efforts by the Chinese government to raise awareness about AIDS and quoting Richard Holbrooke stating that he "would remove China from the list of countries in denial"). 
five strains in 2004, China in November 2005 responded to WHO pressure and promised to speed the delivery of another twenty avian influenza virus samples from 2004 and 2005 to support global efforts to prevent an influenza pandemic. China's response was in sharp contrast to Indonesia's reaction, which was using the idea of "viral sovereignty" to justify its failure to cooperate with WHO in avian influenza sample sharing and disease reporting..$^{73}$

The incentive to pay heed to international opinion is particularly strong when a convincing case could be made that a failure to do so would tarnish China's international image. The visit of China's AIDS crusader, Dr. Gao Yaojie, to the United States in 2007 is a good case in point. She was placed under house arrest as she was leaving for Beijing to pick up a U.S. travel visa so she could attend a banquet to be held in her honor by a nonprofit group whose honorary chairwoman was Senator Hillary Rodham Clinton. However, after Senator Clinton brought her case to President Hu and Vice Premier Wu Yi, the Chinese government, apparently wanting to assuage international criticism, relented and granted permission to her visit to the United States. ${ }^{74}$

\section{B. Growing Interest in Multilateralism}

Beginning in the early 1990 s, as part of its search for an effective approach to allay the fear of the rapidly rising Chinese power, Beijing increasingly turned to multilateralism in its foreign policy. ${ }^{75}$ According to a Chinese scholar, Beijing's participation in multilateral international institutions and efforts to undertake broad multilateral diplomacy is "the most lively and most active component of Chinese diplomacy." 76 The change is evident in its growing participation in multilateral arrangements on international health cooperation at global, regional, and subregional levels (see Table 2). At the global level, China has demonstrated strong interest in working closely with major international organizations in disease prevention and control. In January 2006, China hosted an International Pledging Conference on

73. Richard Holbrooke \& Laurie Garrett, 'Sovereignty' That Risks Global Health, WASH. POST, Aug. 10, 2008, available at http://www.washingtonpost.com/wp-dyn/content/ article/2008/08/08/AR2008080802919_pf.html.

74. Benjamin Kang Lim, Freed China AIDS Activist Off to U.S., ReuTERS, Feb. 25, 2007, available at http://www.reuters.com/article/topNews/idUSPEK19911220070225.

75. See generally ChINA TURnS To MULTILATERALISM: ForEIGN POLICY AND REgIONAL SECURITY (Guoguang Wu \& Helen Lansdowne eds., 2008).

76. Su Changhe, Zhoubian zhidu yu zhoubian zhuyi-Dongya quyu zhili zhong de Zhongguo tujing [Zhoubian Institutions and Zhoubianism: China's Approach to Governance in East Asia], SHIJIE JINGJI YU ZHENGZHI [WORLD ECON. \& POL.], issue no. 1, 2006, at 12 . 
Avian and Human Influenza, which it cosponsored with the European Commission and the World Bank. The Chinese Foreign Minister, rather than the Health Minister, sent out the invitations for this conference. Representatives from more than one hundred countries around the world and representatives of international technical and financing agencies, organizations, the private sector, and civil society attended the meeting. During this event, the international community pledged U.S.\$1.9 billion in financial support, including U.S. $\$ 10$ million from China.

Even compared to its increased participation at the global level, China appears to be more active in participating in regional platforms, including the ASEAN+3 Summit, the East Asia Summit, and the Asia Europe Meeting (ASEM). ${ }^{77}$ Through these venues, China proposed a series of important initiatives on the control of avian flu and the management of public health emergencies. In addition, China has worked with the other five countries in the Greater Mekong Subregion (GMS) in an attempt to institutionalize coordinated surveillance and response to infectious diseases, such as avian influenza. It sponsored the Greater Mekong Six-Nation Ministerial Meeting on Disease Surveillance Cooperation Project and also hosted the second GMS Public Health Forum in 2009.78

\section{Table 2. China's Multilateral Cooperation in Health}

\begin{tabular}{|c|c|c|}
\hline Level & Venue & China's Contribution \\
\hline Global & $\begin{array}{l}\text { U.N., WHO, World Bank, } \\
\text { UNESCO }\end{array}$ & $\begin{array}{l}\text {-Helped revise IHR (2005); } \\
\text {-Hosted and cosponsored International } \\
\text { Pledging Conference on Avian and Human } \\
\text { Influenza (2006). }\end{array}$ \\
\hline Regional & $\begin{array}{l}\text { APEC (Health Working } \\
\text { Group), ASEM (Health } \\
\text { Cluster), ASEAN+3, } \\
\text { ASEAN Regional Forum, } \\
\text { SCO, East Asia Summit, } \\
\text { Asia Cooperation }\end{array}$ & $\begin{array}{l}\text {-Proposed an ASEM initiative on the } \\
\text { management of public health emergencies } \\
\text { (2003); } \\
\text { - Hosted the third ACD, which vowed to } \\
\text { establish a regional disease and epidemic } \\
\text { database and emergency medical }\end{array}$ \\
\hline
\end{tabular}

77. This is consistent with the finding that China's multilateralism is still more regional than global. See Guoguang Wu, Multiple Levels of Multilateralism: The Rising China in the Turbulent World, in CHINA TURNS TO MULTILATERALISM, supra note 75, at 267, 287.

78. See generally Yang Ronggang, Woguo duiwai weisheng jiaoliu yu hezuo jiaqiang [Strengthening Our Country's Foreign Health Exchange and Cooperation], JIANKANG BAO [HEALTH NEWS] (P.R.C.), Dec. 20, 2001, at 1 (describing China's emerging international links in foreign health exchange). 
PUrsuing Health as Foreign Policy: The Case of China 125

\begin{tabular}{lll}
\hline Dialogue (ACD) & assistance system (2004); \\
& - Proposed to make the management of \\
& public health emergencies a key area for \\
& 10+3 cooperation (2005); \\
& -Proposed to host the ASEM Workshop \\
& on Avian Influenza Control in 2007 (2006); \\
& -Proposed that a regional disease \\
& monitoring network be set up to enhance \\
& the capacity of East Asian countries to \\
& respond to public health emergencies \\
& & (2007). \\
\hline Subregional & GMS Health Forum & Initiated the forum in 2005 and hosted the \\
& & forum in 2009.
\end{tabular}

\section{Direct Involvement of Top Leaders}

Beginning with Premier Wen Jiabao's SARS diplomacy in 2003, top government leaders themselves were directly involved in China's health diplomacy. In 2005, Premier Wen suggested deepening the ASEAN+3 mechanism by making the handling of public health emergencies a priority. He also proposed that a ten plus one seminar on post-disaster disease prevention be held under the China-ASEAN Fund for Public Health. In September 2005, President $\mathrm{Hu}$ and President Bush hammered out the "Ten Core Principles" of global pandemic response, which were later supported by eighty-eight nations and agencies. ${ }^{79} \mathrm{On}$ May 6, 2009, Hu personally called President Obama to discuss the spread of H1N1 influenza. Even though the United States had only two H1N1 fatalities at that time, Hu expressed his "sincere condolences" and the desire to "maintain communication with the World Health Organization, the United States, and other relevant parties, as well as strengthen cooperation, to jointly deal with this challenge to human health and safety." 80

The engagement of the top Chinese leaders in health diplomacy has not been confined to making phone calls or initiating new projects. In 2006, Chinese leaders led a successful campaign to elect Margaret Chan

79. Responding to the Threat of Global, Virulent Influenza: Hearing Before the S. Comm. on Foreign Relations, 109th Cong. 2 (2005) (testimony of Laurie A. Garrett, Senior Fellow for Global Health, Council on Foreign Relations).

80. Hu Jintao and U.S. President Barack Obama with a Telephone, XINHUA NEws [P.R.C], May 6, 2009, available at http://news.xinhuanet.com/newscenter/2009-05/06/ content_11325709_1.htm. 
as the Director-General (DG) of WHO. The decision to support Chan's candidacy, the campaign strategies, and election outcomes proved their deftness in using health diplomacy to achieve China's foreign policy objectives. In June 2006, China nominated Chan (then WHO Assistant DG) to be the first Chinese candidate running for WHO DG. To many, Chan was an unexpected choice. A native Hong Kong resident, she was no part of China's domestic political power structure or diplomatic missions. She appeared to be less experienced than her prominent Chinese colleague at WHO, Liu Peilong. In fact, three years ago Beijing was against her appointment as an assistant director-general.81

But Chan's Hong Kong identity, together with her liberal technocratic experience, and her apolitical reputation made her the best choice for Beijing to "redress its closed-door autocratic image projected during its own SARS crisis." 82 After initial hesitation, an ad hoc group led by the then-Vice President Zeng Qinghong decided to throw China's support to Chan. ${ }^{83}$ In campaigning for her, China mobilized all its diplomatic resources. Through phone calls and letters, Foreign Minister Li Zhaoxin and Health Minister Gao Qiang lobbied hard for Chan. The Ministry of Foreign Affairs even issued a general mobilization order to its embassies in the thirty-three countries that served on the WHO Executive Board, asking them to use various means to campaign for votes. Meanwhile, President $\mathrm{Hu}$ and Premier Wen sent personal recommendation letters to leaders of most member states of WHO's Executive Board. President Hu called President Bush to seek U.S. support. ${ }^{84}$ During the Ministerial Meeting of the Forum on China-Africa Cooperation (FOCAC) held November 3-5, 2006, Chinese leaders actively canvassed African votes for Chan. To sweeten the deal, President $\mathrm{Hu}$ promised to double development assistance to Africa for the next three years and to provide preferential credit to Africa worth U.S. $\$ 5$ billion by 2009 . These efforts paid off on November 9 , when Chan defeated twelve other candidates to become the first Chinese to head a major U.N. agency. Chan's representation of China in running for the position and her successful election not only improved China's public image in international health, but also served well Beijing's realist

81. See Andrew Jack, Woman in the News: Margaret Chan, Financial Times, May 8, 2009, available at http://www.ft.com/cms/s/0/a4fc8e58-3c01-11de-acbc-00144feabdc0, dwp_uuid=d7b5a5de-07de-11de-8a33-0000779fd2ac.html?nclick_check=1.

82. Simon Shen, Borrowing the Hong Kong Identity for Chinese Diplomacy: Implications of Margaret Chan's World Health Organization Election Campaign, 81 PAC. AFF. 361, 370 (2008).

83. Interview with a Beijing University professor (July 10, 2009) (on file with author).

84. See Wang Yunquan, Zhongguo tiezui Sha Zukang [China's Iron-mouthed Sha Zukang], RENMIN RIBAO HaIWAI BAN [PEOPLE'S DAILY OvERSEAS EdITION] (P.R.C.), Apr. 4,2007 , at 7 . 
foreign policy agenda. In the words of President $\mathrm{Hu}$, Chan's victory "shows that China's international status has improved." 85 China, of course, gained more than just international recognition of its rising power. During the $2009 \mathrm{H} 1 \mathrm{~N} 1$ outbreak, the government referenced several times the support of Chan and WHO in justifying its aggressive response toward the outbreak, while Chan herself refused to criticize China for its travel and trade restrictions that clearly clash with her agency's advice. ${ }^{86}$

\section{Reinvigorated Health Diplomacy in Africa}

Africa continues to be a priority of China's health diplomacy. In 2003, nearly eighty-one percent of the Chinese foreign aid medical personnel were stationed in Africa, where about seventy-two percent of the countries that have diplomatic relations with China were still hosting China foreign aid medical teams. ${ }^{87}$ The determination to sustain China's health diplomacy in Africa was expressed in an official paper issued by the Chinese government in January 2006.88 By then, China had sent a total of 16,000 medical personnel to forty-seven African countries and regions, and served some 240 million people. ${ }^{89}$ At present, thirty-eight Chinese medical teams are distributed in 108 clinical stations in Africa. 90

As Chinese President Hu Jintao put it, among all the cooperation projects between China and Africa, the dispatch of Chinese medical teams "has the longest history, involves the largest number of countries,

85. Press Conference, Ministry of Foreign Affairs (P.R.C.) ( Nov. 30, 2006), available at http://cn.chinareviewnews.com/doc/1002/6/0/2/100260242.html?coluid=9\&kindid=1911\&do cid $=100260242 \&$ mdate $=0911123624$.

86. See Shan Juan, China 'Did Not Overreact to H1N1 Threat', ChINA DaILY, June 4, 2009, available at http://www.chinadaily.com.cn/cndy/2009-06/04/content_8242279.htm; Li Keqiang, Speech at Beijing H1N1 Conference (Aug. 21, 2009), available at http://paper.people.com.cn/rmrb/html/2009-08/22/content_324800.htm. For Chan's refusal to criticize China, see Andrew Jack, supra note 81.

87. Weishengbu guoji hezuosi [Div. of Int'l Cooperation, Ministry of Health], Jiaqiang shishi xin zhanlüe, gaige yuanzhu Feizhou yiliao gongzuo [Strengthening the Implementation of New Strategy, Reforming Aid-to-Africa Medical Work], XIYA FEIZHOU [WEST ASIA \& AFR.], issue no. 5, 2003, at 15 (P.R.C.).

88. Ministry of Foreign Affairs of the People's Republic of China, China's African Policy (Jan. 12, 2006), available at http://chinese-embassy.org.za/eng/zxxx/t230615.htm.

89. Jin Yong, Zhongguo nüyisheng de "Feizhou qingiie" [Female Chinese Doctor's "African Complex"], ZHongGuo FunÜ Bao [ChINA WOMEN's NewS] (P.R.C.), Nov. 4, 2006, at 2 .

90. Wang Liji, Zhongfei weisheng hezuo jiwang kailai [Carrying Forward the Cause of Sino-African Health Cooperation], GuoJI Shangbao [INT'L CoM. DaILy] (P.R.C), Nov. 5, 2007, at F3. 
and is the most successful."91 Beneficiaries of their services include both the general public and the "upper class" in recipient countries. ${ }^{92}$ In Zambia, for example, patients of Chinese medical teams included the President, the Foreign Minister, the Army Commander, and the wife of the Education Minister. ${ }^{93}$ In Sierra Leone, one Chinese doctor allegedly developed good relations with President Ahmad Tejan Kabbah, the Vice President, and many cabinet ministers. ${ }^{94}$ Official media claimed that the friendship Chinese physicians nurtured with African leaders not only became an important source of information for the local Chinese embassy, but also helped project China's "soft power" and achieve its desired foreign policy objectives, including China's position on human rights, its bid for the 2008 Olympic games, and its application for WTO membership. ${ }^{95}$

Over time, China's cooperation with African countries on health has increasingly targeted practical grassroots projects that have immediate benefits for African social and economic well-being. In recognition of the devastating impact of malaria in Africa, the Chinese Ministry of Foreign Affairs organized anti-malaria training sessions for thirty-four African countries. Based on the Chinese-developed anti-malaria drug Artemisinin and its own experience in combating the disease, China developed programs of malaria control and treatment within the FOCAC framework. The objective was to use such projects to improve the image of Chinese enterprises and establish "all-around cooperation" at government, expert, and enterprise levels. ${ }^{96}$

91. Wang Tian \& Wu Wenbin, Hu Jintao qinqie huijian Zhongguo yuanzhu Moluoge yiliaodui duiyuan [Hu Jintao Personally Meets with Members of China's Moroccan Foreign-aid Medical Team], PEOPLE's DAILY, Apr. 27, 2006, at 1.

92. He Tao, Zoujin shenmi de Guangdong yuanfei yiliaodui [Walking into Mystery, the Guangdong Aid-to-Africa Medical Team], GUANGZHOU RIBAo [GUANGDONG DAILY], July 5, 2006.

93. See Dai Xiaobin \& Feng Pugang, Qingii Zanbiya-wojun yiliaodui yuanZan zhaji [Emotional Ties to Zambia-Notes of Our Army's Aid-to-Zambia Medical Team], JiEFANGJUN JiANKANG [PLA HeALTH], issue no. 6, 1995, at 7-9 (P.R.C.); Li Xianjie \& Li Ling, Zoujin Zanbiya zongtongfu de Henan yisheng [The Henan Doctor Who Walked into Zambia's Presidential Palace], Zhongzhou TONGZHAN [UNITED Front of Henan], issue no. 1, 2003, at 30-31 (P.R.C.) (describing a close relationship developed between a Chinese foreign aid doctor and the President of Zambia).

94. Luo Manyuan, YuanFei jiahua. "Zhongguo shenyi" [Aid-to-Africa Anecdotes: "A Divine Chinese Doctor"] XIANG CHAo [HunAN TIDE], issue no. 2, 2007, at 47-49 (P.R.C.).

95. See generally Bates Gill \& Yanzhong Huang, The Sources and Limits of China's Soft Power, SURVIVAL, Summer 2006, at 17-36 (examining China's increasing soft-power resources and constraints on China's use of such resources); Lu, supra note 15 (discussing the benefits in China's international projects coming out of the acclaim for China's foreign aid programs).

96. Wang Cheng, Zhuazhu jihui, jinjun Feizhou [Seizing Opportunity, the March to Africa], PeOPLE'S DAILY, Apr. 13, 2004, at 7, available at http://www.people.com.cn/ 
At the Sino-African Summit in November 2006, President $\mathrm{Hu}$ pledged to build thirty hospitals and provide U.S.\$37.5 million in grants to supply Artemisinin and develop thirty malaria prevention and treatment centers in Africa. In addition to promoting international development, China's health diplomacy serves another important governance function of foreign policy: promoting and protecting human dignity through the provision of humanitarian assistance. ${ }^{97}$ China has also become increasingly interested in applying health diplomacy to international disaster relief efforts, which are not confined to Africa. Chinese medical teams were among the first medical aid teams to arrive after the 2003 earthquakes in Algeria and Iran and after the 2005 tsunami in Southeast Asia. ${ }^{98}$

However, Beijing's health diplomacy in Africa is by no means entirely altruistic. It is also driven by its desire to secure access to natural resources on the continent. For example, in return for a U.S.\$9 billion deal with the Democratic Republic of Congo that would see the building of infrastructure facilities including thirty-two hospitals and 145 health centers, China would get ten million tons of copper and 400,000 tons of cobalt. ${ }^{99}$ But, even with this caveat, it is safe to say that, especially compared to the 1960 s and 1970 s, health now features more prominently in Chinese foreign policy in all four basic functions of foreign policy, namely, security, economic well-being, international development, and human dignity. 100

\section{E. Southeast Asia: A New Regional Priority}

Since 2003, China has been actively engaging Southeast Asian countries in health-related cooperation. In its cooperation with ASEAN countries, China has focused on combating diseases as a NTS threat, thereby creating a stable security environment for its economic development while reassuring regional nations that its rise does not threaten them. Several unique factors drive the emphasis on NTS threats in China's cooperation with ASEAN countries. The first is geographic proximity. According to Barry Buzan et al., security concerns

GB/paper464/11770/1060885.html.

97. David P. Fidler, Health as Foreign Policy: Harnessing Globalization for Health, 21 HEALTH PROMOTION INT'L 51, 53-54 (2007).

98. See Feng Wei, Guogan jizhi de Zhongguo yiliao jiuyuan diyi bing-fang Zhongguo guoji jiuyuandui shouxi yiliaoguan, Wujing zongyuan fuyuanzhang Zheng Jingchen jiaoshou [The Model of China Medical Assistance-Interview with Zheng Jingchen, Chief Medical Officer, China Medical Assistance International, Vice President of Wujing General Hospital], ZHONGGUO YNUUAN [CHINESE HOSPITALS], issue no. 11, 2006 (P.R.C.).

99. Nick Mathiason, New Fight for Congo's Riches, THE OBSERVER, June 29, 2008, at 7. 100. Fidler, supra note 97 , at 53-54. 
cluster in regions because such concerns do not travel well over distances, making it possible to identify "regional security complexes" as sets of states whose security interests overlap. ${ }^{101}$ China and Southeast Asian countries do share a range of public health problems. Altogether, they account for 91.6 percent of the SARS cases (89.4 percent of fatalities) and, as of June 2008, 79.5 percent of the human cases of avian influenza ( 81.5 percent of fatalities). ${ }^{102}$ This high concentration of health-related NTS threats is different from the distribution pattern of NTS threats in Central Asia/Russia, where the so-called "three forces" (separatism, terrorism, and extremism) are the main security concerns, or Northeast Asia, where nuclear nonproliferation dominates the NTS agenda (see Table 3). ${ }^{103}$

Of course, the distribution of SARS and avian flu cases is asymmetric within ASEAN, and between China and Southeast Asia. ${ }^{104}$ Yet, the openness of their economies and the rapidly developing economic links between them in terms of tourism, trade, and labor movements, means that even countries with few to no cases have to deal with the economic shocks created by the spread of disease in the region. Economic development in Cambodia and Myanmar, for example, suffered in 2003 even though they were spared by SARS.

The high level of broadly defined security interdependence set the dynamics of regional NTS cooperation between China and Southeast Asia differently from those between China and South Asia. As Table 3 shows, even though both China and India face the threats of HIV/AIDS and terrorism, a regional security complex has not emerged, in part because the level of trade interdependence between the two remains low. In 2003, India's share in China's imports was just 1.03 percent,

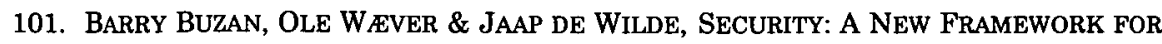
ANALYSIS 70 (1998).

102. For the distribution of SARS cases, see WHO, Summary of Probable SARS Cases with Onset of Illness from Nov. 1, 2002 to July 31, 2003, http://www.who.int/csr/sars/ country/table2004_04_21/en/index.html (last visited Oct. 8, 2009). For information about human cases of avian flu, see WHO, Cumulative Number of Confirmed Cases of Avian Influenza A/(H5N1) Reported to WHO, http://www.who.int/csr/disease/avian_influenza/ country/cases_table_2008_06_19/en/index.html (last visited Oct. 8, 2009).

103. Some Chinese scholars treat nuclear nonproliferation as an NTS challenge. See, e.g., Liu Qing, Dongya feichuantong anquan [Nontraditional Security in East Asia], GuoJI WENTI LUNTAN [INT'L STUD. F.], Summer 2007, at 69, available at http://www.siis.org.cn/Sh_Yj_Cms/Mgz/200702/2008517163412RQIN.PDF.

104. China alone claimed 87.5 percent of all the SARS cases and 83.7 percent of deaths. Id. Among ASEAN countries, human cases of avian flu were found mainly in Indonesia and Vietnam. Id. 
while China's share in India's imports was less than five percent. ${ }^{105}$ The same figures for ASEAN-China trade were 11.5 percent and 7.9 percent, respectively. ${ }^{106}$ The geographic proximity and the relatively high level of economic interaction and interdependence legitimize the "securitization" of public health challenges in China's cooperation with Southeast Asia, which in turn contributed to the building of the "ten plus one" cooperation framework (see Table 3).

Table 3. China and Regional Cooperation on Nontraditional Security Threats

\begin{tabular}{lllll}
\hline \hline Region & $\begin{array}{l}\text { Southeast } \\
\text { Asia }\end{array}$ & South Asia & $\begin{array}{l}\text { Central Asia } \\
\text { and Russia }\end{array}$ & $\begin{array}{l}\text { Northeast } \\
\text { Asia }\end{array}$ \\
\hline $\begin{array}{l}\text { Common } \\
\text { threats }\end{array}$ & $\begin{array}{l}\text { Drug } \\
\text { trafficking; } \\
\text { Infectious } \\
\text { disease } \\
\text { (SARS, } \\
\text { Avian Flu) }\end{array}$ & $\begin{array}{l}\text { Terrorism; } \\
\text { HIV/AIDS }\end{array}$ & $\begin{array}{l}\text { "Three forces" } \\
\text { (terrorism, } \\
\text { separatism, } \\
\text { extremism); } \\
\text { drug } \\
\text { trafficking }\end{array}$ & $\begin{array}{l}\text { Nuclear } \\
\text { proliferation }\end{array}$ \\
& & & High & High \\
\hline $\begin{array}{l}\text { Interaction } \\
\text { level }\end{array}$ & High & Low & & \\
\hline $\begin{array}{l}\text { Cooperation } \\
\text { mechanism }\end{array}$ & ASEAN plus & None & Shanghai & Six-Party \\
& China ("ten & & Cooperation \\
plus one") & & Organization & \\
\hline
\end{tabular}

The "ten plus one" framework consists of three levels (see Figure 1). On the top level is the leadership summit. Launched in 1997, the summit determines strategic direction of the overall cooperative effort. At the 2007 summit, Premier Wen Jiabao proposed that a regular information sharing system be set up to address infectious diseases and public health emergencies. Below that level are the ministerial meetings, which provide assistance to the summit. The first health ministerial meeting was held in 2006. The third level is the working mechanism, including Senior Officials Consultation (SOC) at the vice-

105. Biswanath Bhattacharyay \& Prabir De, Promotion of Trade and Investment Between P.R.C. and India: Toward a Regional Perspective, AsIAN DEv. REV. (2005), available at $\mathrm{http} / / /$ indarticles.com/p/articles/mi_qa5498/is_200501/ai_n21364220.

106. ASEAN-China RELATIONS: REALITIES AND PROSPECTS 14 (Saw Swee-Hock et al. eds., 2005); WTO, World Merchandise Imports by Region (2003), http://www.wto.org/ english/res_e/statis_e/its2004_e/section3_e/iii02.xls (last visited Oct. 11, 2009). 
ministerial level and the ASEAN-China Joint Cooperation Committee (ACJCC). While SOC is entrusted with discussing China-ASEAN relations and other international and regional issues, ACJCC is responsible for coordinating overall cooperation. In March 2005, China proposed to include public health and four other areas as priorities for cooperation, which the SOC endorsed in April.

In addition to the three-level mechanisms, there are supporting arrangements including think tanks, conferences, and governmentsponsored funds. For example, the China-ASEAN Eminent Persons Group (CAEPG), composed of retired senior government officials, proposed in 2005 to hold China-ASEAN Ministerial Meetings on newly emerging infectious diseases. China also expressed its willingness to host a symposium on the progress of prevention and control of human cases of highly pathogenic avian influenza. China and ASEAN have established the "China-ASEAN Public Health Fund" to finance the health-related activities and projects. In short, under the ten-plus-one mechanism, efforts have been made to establish regular information sharing and cooperative disease surveillance and control systems on communicable diseases and public health emergencies.

Figure 1. Level of ASEAN-plus-China Cooperation Mechanism over Health

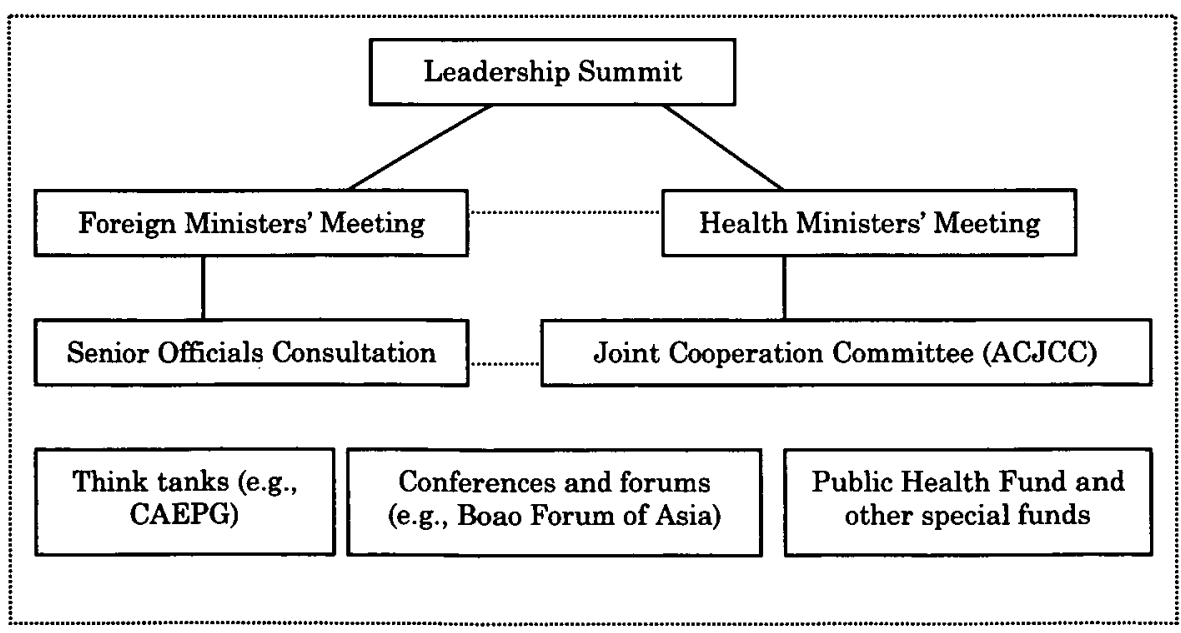

\section{DILEMMaS AND DANGerS}

In justifying U.S. support for global health in its foreign policy, Jordan S. Kassalow offered three rationales: narrow self-interest, enlightened self-interest, and humanitarian interests, and concluded 
that only by blending these approaches would the United States play its appropriate role in promoting global health. ${ }^{107}$ However, these objectives are not always reconcilable. As the following case studies show, when public health issues cascade across its foreign policy agendas, China is bedeviled by some intractable dilemmas and constraints.

\section{A. Global Health vs. State Sovereignty}

One of the main challenges China faces in handling health as a foreign policy issue is to find the proper balance between the traditional emphasis on state sovereignty and universalist ambitions inherent in addressing the global spread of infectious diseases. Noting that SARS spread to twenty-seven countries in four months, Heymann and Rodier argued that "inadequate surveillance and response capacity in a single country can endanger national populations and the public health security of the entire world." 108 This reality led former WHO DG Lee Jong-wook to conclude that "[w]e cannot afford any gap in our global surveillance and response network." 109 Prior to the revision of the IHR in 2005 , however, the reporting of disease outbreaks and the nature of responses to them was solely the domain of sovereign states. The problem is that states have incentives to suppress the flow of information regarding endogenous epidemics, which typically generate strong negative effects upon the economy and society of affected countries.

Worse, laboratory and epidemiological capacities remain weak in the developing world, where the greatest number of new pathogens has been diagnosed over the past two decades. This gap in global surveillance and response led to the revisions of the IHR in 2005, which radically changed the way the world would handle reporting and responses to public health emergencies of international concern. ${ }^{110} \mathrm{By}$ allowing WHO to consider reports from nonstate sources, and by making it mandatory for states to cooperate with WHO in disease surveillance and control, the revised IHR deprived states of the exclusive privilege to report and respond to infectious diseases occurring

107. JoRdan S. Kassalow, Why Health Is Important to U.S. Foreign Policy (Council on Foreign Relations 2001), available at http://www.cfr.org/publication/8315/ why_health_is_important_to_us_foreign_policy.html.

108. David L. Heymann \& Guénaël Rodier, Global Surveillance, National Surveillance, and SARS, 10 EMERGING INFECTIOUS DISEASES 173, 173 (2004).

109. Lee Jong-wook, Dir. Gen., WHO, Address at the 57th World Health Assembly (May 17, 2004), available at http://www.who.int/dg/lee/speeches/2004/wha57/en/index.html.

110. For an overview of the radical changes made in the IHR in 2005, see David P. Fidler, From International Sanitary Conventions to Global Health Security: The New International Health Regulations, 4 CHINESE J. INT'L L. 325 (2005). 
on their territories. Moreover, the revised IHR introduced the principle of universal application "for the protection of all people of the world from the international spread of disease." 111 Under this principle, even political entities that are not WHO members should not be excluded from the WHO global disease control network.

In recognition of the global nature of infectious disease and its initial mishandling of the SARS crisis, Beijing became more responsible and cooperative during the late stages of the anti-SARS campaign. Despite the increasingly assertive role of WHO, Beijing did not complain about the latter's interference in its internal affairs. China also gave a green light to WHO experts to have direct contact with Taiwan, even though it insisted that Beijing was the only legitimate government representing China and that Taiwan was part of China. China also demonstrated flexibility in the revision of the IHR, especially with regard to the inclusion of the universal application principle.112 In 2005, China signed a Memorandum of Understanding (MOU) with WHO in which it agreed that Taiwanese medical experts could enjoy "meaningful participation" in WHO-related activities.

But when universal application became a key facet of Taiwan's diplomatic campaign for formal WHO membership, China viewed those actions as a potential threat to its sovereignty and territorial integrity. In negotiating the revision of IHR, China's chief negotiator, a veteran diplomat, made it clear that "health is a very important issue, but sovereignty and territorial integrity are more important to a sovereign state. China will firmly defend its sovereignty and territorial integrity at all cost." 113 Playing China's sheer population size as a trump card, he further warned that "the future IHR has no universality without China's participation." 114 Insisting that the principle of "universal application" should not undermine the sovereignty of WHO member states, China pushed for the incorporation of additional principles such as "respecting sovereignty of all countries" and "abiding by the United Nations Charter and the World Health Organization (WHO) Constitution."

While allowing WHO to interact with Taiwan, the implementation of the 2005 MOU set out clear restrictive procedures on such contact. Among others, the invitation of Taiwanese health experts or dispatch of

111. WHO, International Health Regulations, at 10 (2005), available at http://www.who.int/csr/ihr/IHR_2005_en.pdf.

112. Interview with a senior Swiss health official (Mar. 10, 2009) (on file with author).

113. Ambassador Sha Zukang, Statement regarding the "International Health Regulations" Amendments to the Working Group Closing Plenary Session (Nov. 12, 2004), http://www.china-un.ch/chn/gihyfy/hy2004/t172226.htm.

114. Id. 
WHO experts to Taiwan should be justified from "both a technical and policy point of view" and must obtain the approval of the Chinese Ministry of Health. ${ }^{115}$ In January 2008, China had the WHO Executive Board pass its proposed amendment reaffirming the sovereignty principle, thereby nullifying a pro-Taiwan proposal that would have amended a draft resolution on IHR implementation to emphasize the principle of universality. ${ }^{116}$

Beijing's insistence on sovereignty and territorial integrity effectively raised the bar for Taiwan's WHO entry. Since 1997, Taiwan has been trying to become an observer in the World Health Assembly, the supreme decision making body of WHO. But the bid failed every time because of opposition by China, which maintained that Taiwan was part of its territory and only sovereign states could join the organization. Beijing's recalcitrance over Taiwan's participation nevertheless was seen as heartless hostility toward Taiwan. Proindependent leaders were quick to point out how China's blockage of WHO assistance to Taiwan was responsible for the spread of infectious diseases on the island.117

The issue embittered the atmosphere of cross-strait relations, and played into the hands of Taiwanese pro-independence leader President Chen Shui-bian, generating strong popular support and international sympathy for his efforts to expand Taiwan's international space. In this context, Beijing's opposition made China look like "a real bully" in front of the world's health ministers. 118 Frustrated that Taiwan's twenty. three million people could not get the observer status at WHO that was held by the Vatican, Liechtenstein, and the Order of Malta, the U.S. Congress geared up its support for Taiwan's participation in WHO. Under strong congressional pressure, President George W. Bush in November 2003 sent Chen a rare personal letter pledging support for Taiwan to be accorded WHO observer status. The tensions between Beijing's claim as an effective regime representing all Chinese territories and its inability to cover all Chinese people living within its sphere of influence, thus, undercut China's ability to project its "soft power," especially with regard to Taiwan.

115. WHO, Implementation of the Memorandum of Understanding Between the WHO Secretariat and China, at 4 (July 12, 2005).

116. ROC Cent. News Agency, WHO Board Passes Chinese Amendment to IHR-Related Bill (Jan. 23, 2008), available at http://www.globalsecurity.org/wmd/library/news/taiwan/ 2008/taiwan-080123-cna01.htm.

117. Donald G. McNeil, Jr., SARS Furor Heightens Taiwan-China Rift, N.Y. TIMES, May 19,2003 , at A8.

118. See id. 
Although Beijing insists that sovereignty is nonnegotiable, what it claims is not de facto but de jure sovereignty. This difference explains why its tough stand on Taiwan's participation as a WHO observer changed after the newly elected Taiwanese president Ma Ying-jeou acknowledged the so-called "92-Consensus" reached by both sides in 1992. Featuring the "One China Principle," the consensus satisfies China's nominal sovereignty concern even though that principle is subject to different interpretation by both sides. Against the backdrop of the recent thaw in cross-strait relations, China offered to lift its objections to the island's participation in world bodies, which paved the way for Taiwan to become an observer at the World Health Assembly in May 2009. ${ }^{119}$

\section{B. Human Security vs. Traditional Security}

When a health problem is framed as a human security challenge, international cooperation to address the problem is expected because, by definition, human security transcends the traditional security dilemma that treats states as competitors whose interactions are always of a zero-sum nature. ${ }^{120}$ In the case of China, government leaders have become more interested in international health cooperation largely because they see diseases as a NTS threat that could harm the national economy, the apparatus of governance, and China's international image. In other words, although China has realized that strategies of self-help are doomed to failure in containing the spread of infectious diseases, it is motivated to action primarily by its narrow self-interest. This cognition-action gap is complicated by the fact that many transnational and nonmilitary NTS threats, including infectious disease, are frequently interwoven with traditional security threats that are biased toward states, their competition, and their concern with relative gains. ${ }^{121}$ Of course, if each state adopts a state-centric view in assessing the threats posed by infectious diseases, differences in interest articulation inevitably lead to competitive dynamics between nations to the detriment of global health.

This dilemma is particularly a problem in China's cooperation with Southeast Asia, where health challenges are intertwined with the traditional "security dilemma." Unlike Europe, Asian countries in the

119. Xie Yu, Taiwan Gets Observer Status at WHA, CHINA DAIlY, May 19, 2009, at 8.

120. JeNNIFER Blower \& PETER ChalK, RAND CorP., THE Global THREAT OF NEW AND REEMERGING INFECTIOUS Diseases: RECONCILING US NATIONAL SECURITY WITH PUBLIC HEALTH POLICY 6 (2003).

121. See Susan L. Craig, Chinese Perceptions of Traditional and Nontraditional SECURITY THREATS 101-29 (2007); see also BLOWER \& CHALK, supra note 120. 
region still lack a strong collective regional identity because of the heterogeneity in cultures and variations in the level of social, economic, and political developments. This "identity gap" in Southeast Asia makes it difficult to reach consensus because it incurs higher transaction costs of cooperation, defined by Williamson as including the ex ante costs of drafting, negotiating, and safeguarding an agreement, and the ex post costs of haggling, costs of governance, and bonding costs to secure commitments. 122

The transaction cost is raised even higher by the competitive engagement of major powers in the region (i.e., United States, China, and Japan). Any major power's attempts to dominate collective security building in this region are likely to meet opposition from other major powers, and ASEAN states are suspicious of any arrangements that would potentially lead to the dominance by a single major power. These dynamics may explain why China's initiative of establishing an antiSARS international fund was not well received in the Bangkok summit in April 2003.123 The lack of trust among nations in this region exacerbates the traditional security dilemma, ${ }^{124}$ which has an adverse effect on global health cooperation. In view of the U.S. presence in the region and ASEAN countries' fear of being swamped by their huge neighbor, China cannot play a dominant role in the collective security building process.

Yet, allowing ASEAN to play a leading role in the process also undermines the efficacy of regional cooperation on health issues. First, other things being equal, the transaction costs of collective security building dominated by major powers are lower. Second, the nonintervention principle long adopted by ASEAN countries can negatively affect international cooperation when responding to NTS crises. As a result, China's cooperation with ASEAN over disease prevention and control is still largely confined to forums, declarations, and dialogues. This "consultative security" or "acquiescent security" is different from the "institutionalized security" or "contractual security" present in Europe. 125

The negative impact of the traditional security dilemma on the incentive and efficacy of cooperation over health is evidenced in China's stance toward the HIV/AIDS crisis in Myanmar. According to the

122. See OLIVER E. WILLIAMSON, THE ECONOMIC INSTITUTIONS OF CAPITALISM 20 (1985). 123. LIANG QINGYIN, FEIDIAN: FANSI YU DUICE [SARS: REFLECTIONS AND COUNTERMEASURES] 231 (2003) (Guangzhou, P.R.C.).

124. Fang Changping \& Xiong Bingdi, Dongya feichuantong anquan hezuo tanjiu $[A$ Study of Non-traditional Security Cooperation in East Asia], JIAOXUE YU YANJIU [TEACHING AND RESEARCH], issue no. 9, 2007, at 61 (P.R.C.).

125. See Wang, supra note 37. 
annual report of the Joint United Nations Program on HIV/AIDS (UNAIDS), Myanmar ranks with Thailand and Cambodia as among the three countries in Southeast Asia with high annual HIV prevalence rates. ${ }^{126}$ While its adult HIV prevalence rate $(0.7$ percent) was less than that of Thailand (1.4 percent) or Cambodia (0.9 percent) in 2006, Myanmar is considered a primary contributor to the spread of HIV/AIDS in Southeast Asia and China, given its extreme poverty, drug trafficking, rampant sex trade, and lack of health care or education programs for people with HIV or vulnerable groups living along its porous borders. The spillover from Myanmar accounts for the high HIV prevalence rate (1.5-2 percent) in the neighboring Yunnan province of China and has fueled a spike in HIV rates in China since the late 1980s. ${ }^{127}$

Viewing the HIV/AIDS epidemic in Myanmar as a threat to international security, a September 2005 report commissioned by former Czech President Vaclav Havel and South African archbishop Desmond Tutu called for the U.N. Security Council to act on the country's failure to address the epidemic. In January 2007, these concerns were included in a resolution introduced by the U.S. government at the U.N. Security Council. China, together with Russia, came to Myanmar's defense by casting vetoes against the resolution on grounds that the situation in Myanmar did not pose a threat to international peace and security. Beijing's veto was significant because it had used it only four times in the past.

Resolving the HIVIAIDS challenges in Myanmar would call for more proactive international intervention, but Myanmar's role as Beijing's long-term strategic ally makes such an intervention too risky and costly for China. China has become Myanmar's second-largest trading partner; it also needs Myanmar to access the oil and gas directly from the Middle East and Africa without passing through the Malacca Strait. According to one Chinese scholar, regional strategic concerns were the main reason behind the U.S. resolution on Myanmar at the U.N. Security Council. ${ }^{128}$ Beijing was convinced that, if the resolution was passed, it might serve as a Trojan horse to bring U.S. influence to bear on Myanmar, which would be against China's foreign policy goal of

126. See UNAIDS, 2008 REPORT ON THE GLOBAL AIDS EPIDEMIC (2008), http://data. unaids.org/pub/GlobalReport/2008/20080813_gr08_prev1549_1990_2007_en.xls.

127. See generally Yanzhong Huang, The Politics of HIV/AIDS in China, 30 ASIAN PERSP. 1, 95-125 (2006).

128. Xiao De, Zhongguo zai lianheguo dongyong foujuequan, Miandian ganxie Zhongguo [China Used Veto Power at UN; Myanmar Thanked China], GUOJ XIANQU DAOBAO [INT'L HERALD TRIB.], Jan. 18, 2007, available at http://sites.google.com/site/shanstatenews1/ 2007011904. 
preventing the U.S. from completing its encirclement of China. This overwhelming concern for traditional security explains China's reluctance to use fully the U.N. Security Council in addressing global NTS threats, such as HIV/AIDS, in spite of the recommendations of some leading policy experts. ${ }^{129}$ It also partially explains why China is not as enthusiastic in cooperating with ASEAN countries over HIV/AIDS as it is over SARS or avian influenza.

Caught between China and the United States, Indonesia, the only ASEAN member on the U.N. Security Council, abstained on the proposed U.S. resolution. Apparently influenced by the nonintervention principle, it echoed China's position that issues like HIV/AIDS "did not make Myanmar a threat to international peace and security" even though "they inflicted suffering on the people of Myanmar."130 Put differently, even though HIV/AIDS should be considered a human security challenge, it did not pose a threat to traditional security, therefore international collective action against Myanmar was not justified. Again, the mixture of traditional and nontraditional security challenges underscored the complexities and challenges China and its neighbors face in institutionalizing their cooperation mechanisms to address public health problems

\section{Science us. Politics}

In conceptualizing the relationship between health and foreign policy, Fidler envisions an approach under which scientific evidence is marshaled for policy purposes through the lens of state interests. ${ }^{131}$ In this way, the science-politics dynamic strikes an appropriate balance between pursuing health as an end in itself and using health as merely a vehicle for statecraft. But he also cautions that the science-politics dynamic can be dangerously unstable. 132 The ability for foreign policy experts to act on the foresight of science can be constrained by the lack of health system capabilities-a problem that is commonly found in countries most at risk of disease outbreaks. The interplay between politics and science becomes particularly a concern when countries are dealing with a novel pathogen, whose etiology, transmission, and virulence are unknown to scientists and policy makers. To navigate the microbial and political worlds' complexities and uncertainties, decision

129. Wang, supra note 37 , at 33 .

130. Press Release, Security Council, Security Council Fails to Adopt Draft Resolution on Myanmar, U.N. Doc. SC/8939 (Jan. 12, 2007), available at http://www.un.org/News/ Press/docs/2007/sc8939.doc.htm.

131. See Fidler, supra note 8, at 185.

132. Id. at 191 . 
makers naturally lean heavily on previous experiences and/or preexisting policy frameworks, adjusting only at the margins to accommodate distinctive features of new situations. ${ }^{133}$ The ability of science to drive interventions against threats to human health may be further compromised as science itself is not always politically neutral. Indeed, once health is transformed from a humanitarian, technical "low politics" issue to one that features prominently on many political agendas, states' responses to public health will be increasingly subordinate to domestic political deliberations and interventions, leading to actions that might have negative repercussions at the international level.

The negative dynamics between health and politics are revealed in China's handling of the recent H1N1 influenza outbreak. A descendant of the 1918 Spanish flu virus, H1N1 is popularly known as "swine flu." However, scientists found it difficult to pinpoint the origin of the virus, to determine how easily the virus spread between people, and to predict how severe the virus will become in the general population. ${ }^{134}$ Unlike its initial response to the SARS outbreak, the Chinese government took swift and decisive actions against the $\mathrm{H} 1 \mathrm{~N} 1 \mathrm{flu}$ from the very beginning. On April 25, 2009, the very day China received reports from WHO about the disease, the government ordered airports to screen stringently inbound passengers from Mexico and other countries that had reported confirmed H1N1 cases. One week later, it suspended direct flights from Mexico after a Mexican passenger who transited through Shanghai was confirmed in Hong Kong to have H1N1 flu. Even though he was the only known Mexican infected with $\mathrm{H} 1 \mathrm{~N} 1$ in China, the authorities rounded up all travelers aboard the flight, including a number of Mexican passport holders who had not been home in months. ${ }^{135}$ According to the Mexican Ministry of Foreign Affairs, China was the only country where Mexicans had been confined against their will. ${ }^{136}$

133. The powerful impact of the past is evidenced in the U.S. handling of the 1976 swine flu outbreak. Convinced by his scientific advisors that the United States could see a return of the 1918 flu virus, President Ford chose to err on the side of caution by launching a mass immunization campaign. Patrick Di Justo, The last great swine flu epidemic, SALON.COM, Apr. 28, 2009, http://www.salon.com/env/feature//2009/04/28/1976_swine_flu' print.html (last visited Oct. 9, 2009).

134. Center for Disease Control and Prevention [CDC], 2009 H1N1 Flu (Swine Flu) and You, http://www.cdc.gov/H1N1flu/qa.htm (last visited Oct. 9, 2009).

135. Andrew Jacobs \& Marc Lacey, Even as Fears of Flu Ebb, Mexicans Feel Stigma, N.Y. TIMES, May 5, 2009, at A1.

136. See Jamil Anderlini \& Andrew Jack, Mexico Hits at China's Quarantine Policy, Fin. TIMES, May 4, 2009, available at http://www.ft.com/cms/s/13f4c296-38d6-11de-8cfe00144 feabdc0.html. 
These measures, initially targeting Mexican nationals, immediately triggered a diplomatic row between China and Mexico. Calling Chinese measures "discriminatory and ungrounded," Mexican Foreign Minister Patricia Espinosa even advised Mexicans to stay away from China. On May 3, Mexico's president lashed out at countries he said were "acting out of ignorance and disinformation" and taking "repressive, discriminatory measures."137 Ironically, just three days later, Espinosa expressed "sincere gratitude" for the humanitarian aid worth U.S.\$5 million offered by China. ${ }^{138}$ The situation had been so tense that the Mexican government chartered a plane to bring home all seventy Mexican citizens being quarantined in China.

As the Mexicans departed, China clashed with Canada over a group of Canadian university students placed in quarantine when they landed at the northeastern city of Jilin on May 2, 2009, despite the fact that they had been cleared through customs in Beijing and none of them had been exposed to the virus or were experiencing any flu-like symptoms. The quarantine prompted the Canadian Embassy in Beijing and WHO to seek clarification from the Chinese government. The timing could not have been worse: it came as the Canadian Foreign Minister Lawrence Cannon prepared to travel to China to try to improve Sino-Canadian relations.

Under international pressure, the quarantine of Canadian students was finally lifted two days earlier than China originally planned. By then, however, China's anti-swine flu measures had complicated SinoCanadian relations. Despite WHO's call for countries not to impose trade restrictions, China's Ministry of Agriculture on April 27 instituted a ban on pork and pork products from Mexico and three U.S. states. China extended the ban to Canada (the third largest pork exporter to China) on May 3 after pigs in Alberta tested positive for the H1N1 flu virus. Although China defended these measures as necessary to block swine flu from spreading to China, the pork ban was hard to justify on public health grounds, as China's Ministers of Health and Agriculture both agreed that swine flu had nothing to do with eating pork. ${ }^{139}$ The lack of a public health justification for the pork ban meant that the ban probably violated the IHR (2005), which require that trade-restrictive health measures be based on WHO recommendations or a legitimate public health justification provided to WHO upon request. Accusing

137. $I d$.

138. Chinese, Mexican FMs Talk Over Phone About Swine Flu, People Daily Ondine, Apr. 30, 2009, http://english.peopledaily.com.cn/90001/90776/90883/6648332.html (last visited Oct. 9, 2009).

139. Luke Meredith, US Pork Industry Baffled by Bans in China, Russia, A.P. Fin. WIRE, June 4, 2009. 
China of "operating outside of sound science," the Canadian Agriculture Minister threatened to file a complaint with the WTO if China did not lift the ban. ${ }^{140}$

China is not the only country whose relations with Mexico soured because of the H1N1 outbreak; neither is it the only one that banned pork imports from North America. ${ }^{141}$ What is puzzling is that China sustained and even stepped up its efforts to contain the spread of the $\mathrm{H} 1 \mathrm{~N} 1$ virus, as the situation in Mexico stabilized and many countries decided to scale down their response measures after gaining more information about the disease. ${ }^{142}$ On May 22, China began screening every inbound international flight. According to the information provided by the International Air Transport Association in mid-June, China was the only nation conducting onboard temperature checks and quarantining groups of passengers. ${ }^{143}$ If a passenger was found to have a fever, at least part of the plane was quarantined. ${ }^{144}$ For those who had cleared customs, they were still subject to enforced quarantine in government-designated facilities if found to have had close contact with even a suspect case. One day after his arrival in Shanghai in early June, for example, New Orleans Mayor Ray Nagin was held in quarantine simply because a passenger in the row ahead of him exhibited flu-like symptoms. The quarantining smacked of an Orwellian approach to public health. Indeed, as this article was being written, China was still holding several thousand people in government quarantine facilities. Among all the affected countries, China has been the most draconian in responding to the H1N1 outbreak.

The Chinese Foreign Ministry spokesman defended such aggressive and intrusive measures as "purely a matter of public health."145 But are

140. Canada Threatens WTO Complaint for China Pork Ban, ECON. TmES, May 5, 2009, available at http://economictimes.indiatimes.com/News/International-Business/ Canada-threatens-WTO-complaint-for-China-pork-ban/articleshow/4486495.cms.

141. For examples of countries acting "irrationally," see Jose Carreno Figueras, Mexico Bitter About Panic Over Swine Flu, WASH. TIMES, May 14, 2009, at B3.

142. For example, Singapore after mid-May no longer required passengers returning from Mexico to be subject to enforced self-quarantine. See Editorial, Youbei wuhuan rengshi kang liugan shangce [Preparedness Remains the Best Strategy Against the Flu], LiAnhe ZAOBAo [UNITED MORNING PAPER] (Singapore), May 18, 2009, available at http://www.zaobao.com/special/birdflu/pages3/birdflu090518b.shtml.

143. Simeon Bennett, They Shoot Frequent Fliers, Don't They? Only in China's Flu Era, BLOOMBERG.COM, June 21, 2009, http://www.bloomberg.com/apps/news?pid=newsarchive $\&$ sid=a3hHFvo8NN1k (last visited Oct. 18, 2009).

144. Until early June, the entire plane would be quarantined if one person was found to have flu symptoms.

145. Ariana Cha, Caught in China's Aggressive Swine Flu Net; Quarantine Measures Keep Cases Down but Virtually Imprison Healthy Travelers, WASH. POST, May 29, 2009, at A1. 
the measures scientifically justifiable? The pork ban was clearly a nonsensical method of disease control, given the predominately humanto-human transmission of $\mathrm{H} 1 \mathrm{~N} 1$ and the safety assurances Beijing has received from WHO and the World Organization for Animal Health. In light of these facts, experts speculated that the government was using the swine flu scare as a convenient excuse to restrict imports and give a boost to the country's hog industry, which saw a 28.6 percent drop in pork prices in April. ${ }^{146}$ This theory is supported by the finding that, prior to the H1N1 flu outbreak, China "had deployed several arguments to try to keep out American pork." 147 Indicating that China was exploiting legitimate concern over public health to engage in protectionism, the U.S. Agricultural Secretary warned that any actions not based on sound science "could do extraordinary damage, not just to our economy but to those of other countries, as well."148

Given the uncertainty surrounding the $\mathrm{H} 1 \mathrm{~N} 1$ virus and the prospect of $\mathrm{H} 1 \mathrm{~N} 1$ mixing with $\mathrm{H} 5 \mathrm{~N} 1-$ the highly lethal avian influenza virus that appears to be endemic in China-other measures such as stricter medical checks and quarantine appeared to be more justifiable. Having been criticized for their belated response during the initial stage of the SARS outbreak, decision makers in Beijing were sensitive to allegations that they were not reacting responsibly to health crises. After all, China was still gripped by memories of SARS when responding to the H1N1 outbreak. Indeed, the official guidelines on $\mathrm{H} 1 \mathrm{~N} 1$ prevention and control unveiled on May 1 clearly targeted a SARS-like virus. Apparently having SARS in mind, a health ministry spokesman said that "[a] largescale breakout would be fatal for China."149 The failure to differentiate between SARS and H1N1 in terms of their transmissibility and virulence nevertheless made the draconian and intrusive border control and quarantine measures not as effective as the government claimed. For one thing, SARS carriers are only contagious when they show symptoms, but, in the case of H1N1, asymptomatic people can shed the virus. Of the 35.7 million visitors checked from April 25 to July 15, only 0.04 percent were found to have signs of flu, and 455 people, or about one per 100,000 visitors, were confirmed to have H1N1 flu. ${ }^{150}$

146. China's CPI Falls $1.5 \%$ in April, CHINA DAILY, May 11, 2009, available at http://www.chinadaily.com.cn/bizchina/2009-05/11/content_7762947.htm.

147. Editorial, Of Pigs, Planes and Protectionism, N.Y. TIMEs, May 10, 2009, at WK7.

148. Spencer S. Hsu, U.S. Warns Other Nations Not to Ban Pork, WASH. PoST, Apr. 29, 2009, at A7.

149. See Bennett, supra note 143.

150. See General Administration of Quality Supervision, Inspection and Quarantine of the People's Republic of China, Inspection and Quarantine Authorities Confirm 455 Cases of H1N1 During Port Inspections, July 15, 2009, available at http://www.aqsiq.gov.cn/ zjxw/zjxw/zjftpxw/200907/t20090717_122065.htm. 
Of the total number of confirmed cases by July $15(1,444)$, border screening identified less than one third of the cases. Similarly, there is no indication that rounding up apparently healthy individuals and confining them to government-designated facilities worked as an effective method of disease control. The influenza virus is much more infectious and moves too fast to be contained in the same way as SARS. Based on the epidemiological data provided by the Ministry of Health and the Chinese Center for Disease Control, this research finds that as of June 18 (date of the most recent epidemiological data available as of this writing), only twenty-three confirmed cases were identified through "concentrated medical observation," a euphemism for enforced quarantine. If we combine these cases with the ninety confirmed cases identified as a result of strict border screening, a total of 113 cases, or 37.4 percent, were identified through the strict border control and quarantine measures. ${ }^{151}$ This information means that more than sixty percent of the cases were identified through self-reporting.

Even if the heavy-handed approaches are not scientifically justified, they make perfect political sense. Forceful measures, such as enforced quarantines and travel restrictions, are widely credited with helping stop the spread of SARS, so it was no surprise that the Chinese government made them the silver bullet for all infectious diseases. In the eyes of government leaders, the failure to differentiate between different viruses is secondary as compared to having a visible approach the top leaders want to demonstrate to the Chinese people and the international society. The political leaders were more interested in presenting an image that the government was acting differently from SARS, that it indeed placed top priority on people's health and wellbeing.

On the eve of the twentieth anniversary of the Tiananman crackdown, the government's forceful action against H1N1 helped shore up its legitimacy. A survey conducted by the China Youth Daily

151. By June 18, according to the Chinese CDC, there were a total of 302 cases. Zhongguo jibing yufang kongzhi zhongxin [Chinese Ctr. for Disease Control \& Prevention], 09 nian 6 yue 19 ri woguo xinzeng jiaxing H1N1 liugan quezhen bingli 75 li [June 19, 2009: Newly Increased Influenza A HIN1 Confirmed Cases, 76 Cases], http://www.chinacdc.net.cn/n272442/n272530/n273736/n273781/n4624704/n4624712/3196 3.html (last visited Oct. 9, 2009). GAQSIQ provided data on the cases confirmed through border screening from April 25 to June 18. Guojia zhiliang jiandu chayan chayi zongju [Gen. Admin. of Quality Supervision, Inspection \& Quarantine], Jiezhi 6 yue 18 ri, zhijian zongju suoshu churujing jianyan jianyi jigou zai rujing kouan yi faxian 90 li jiaxing H1N1 liugan quezhen bingli [As of June 18, GAQSIQ Border Inspection Organs Have Already Discovered 90 Confirmed Cases of Influenza A H1N1 at Ports of Entry], June 19, 2009, http://www.aqsiq.gov.cn/zjxw/zjxw/zjftpxw/200906/t20090619_118957.htm (last visited Oct. 9, 2009). 
suggests that eighty-five percent of the Chinese expressed satisfaction with the draconian government measures. ${ }^{152}$ To be sure, Communist Party leaders emphasized "science" and the "rule by law" in undertaking the anti-H1N1 measures. Yet, when they made H1N1 prevention and control a top national priority and warned that it would punish any failures to monitor or report the spread of the disease, nonscientific, heavy-handed measures became more appealing to local government officials. As shown in the Jilin quarantine case, policy implementers found it safer to be overzealous than to be seen as "soft." In sum, once health became a common denominator for political action, it reversed the science-politics dynamics, generating negative repercussions for foreign relations and global health governance.

\section{CONCLUSION}

In the Cold War era, the health-foreign policy dynamics in China took the form of a limited "health diplomacy" that served a foreign policy agenda reflecting China's hostility toward the existing international order. National and international developments in the 1980 s and $1990 \mathrm{~s}$, as well as the 2002-03 SARS crisis, reshaped the discourse on security and foreign policy, leading to a "health as foreign policy" transformation that saw profound changes in the substance and style of China's participation in international cooperation on health. As the government recognizes the importance of health in fulfilling all the governance functions of foreign policy (security, economic well-being, international development, and human dignity), it pursues health as a foreign policy concern in its fullest sense. Furthermore, China's engagement in international health has become more active, sophisticated, multilateral, and transparent. These developments have contributed to the achievement of its desired foreign policy objectives, on the one hand, and improvement in global health, on the other.

However, China's active engagement in global health is primarily driven by a foreign policy agenda that focuses on expanding international influence while improving international image. Although China recognizes that solutions to global health problems necessitate neoliberal strategies of cooperation over disease prevention and control, its actions on global health problems are still justified from the lens of classical realism that focuses on power, influence, and security. The efforts to utilize health initiatives to promote narrowly defined national

152. Huang Chong, $85.2 \%$ gongzhong manyi Zhongguo fangkong jiaxing H1N1 liugan jucuo [85.2\% of the Public Are Satisfied with the Measures Taken to Prevent and Control Influenza $A H 1 N 1$ ], ZHONGGUO QINGNIAN BAO [CHINA YOUTH DAILY] (P.R.C.), May 26, 2009, available at http://zqb.cyol.com/content/2009-05/26/content_2682266.htm. 
interests, as demonstrated in Margret Chan's WHO DG campaign and China's reinvigorated health diplomacy in Africa, may produce benefits that trickle down in terms of facilitating global health governance or improving international health status. The danger is that when health is placed in the realm of realpolitik, it runs the risk of being "dependent on the logic of such politics-which is not based on science and not subject to public deliberation and peer review, but on the Machiavellian instincts of those in power."153

This tension helps explain why China, in its pursuit of health as foreign policy, is still constrained by the traditional concerns of sovereignty and national security. The two dilemmas (state sovereignty vs. global health, traditional vs. nontraditional security) not only hinder the fulfillment of China's foreign policy objectives, but also undermine the incentives and efficacy for China to engage in international health. In essence, the emergence of such dilemmas signals the connection of health policy to "a kind of permanent dialogue between Rousseau [the realist] and Kant [the idealist]." 154 This sobering reality can be compounded by the growing emphasis on health as a preeminent domestic political value for the Communist Party and its leadership. As shown in China's overreaction on $\mathrm{H} 1 \mathrm{~N} 1$, the politicization of public health problems can lead a country to pursue a political agenda that does not address the needs or concerns of others, and which eventually undercuts trust and goodwill among states. In short, China's pursuit of health as foreign policy presents both opportunities for and risks to global health governance.

153. Konrad Obemann, Global Health and Foreign Policy, THE LANCET, May 2007, at $1688,1688$.

154. David P. Fidler, Reflections on the Revolution in Health and Foreign Policy, BuLL. OF THE WORLD HEALTH ORG., Mar. 2007, at 243, 243 (quoting Stanley Hoffmann). 